NBER WORKING PAPER SERIES

\title{
INTEREST RATES AND THE DESIGN OF FINANCIAL CONTRACTS
}

\author{
Michael R. Roberts \\ Michael Schwert \\ Working Paper 27195 \\ http://www.nber.org/papers/w27195 \\ NATIONAL BUREAU OF ECONOMIC RESEARCH \\ 1050 Massachusetts Avenue \\ Cambridge, MA 02138 \\ May 2020, Revised January 2022
}

We thank Patrick Bolton, Urban Jermann, Craig Leonard, Yueran Ma, Mark Mitchell, Christian Opp, Bill Schwert, Daniel Streitz; seminar participants at the University of British Columbia, the University of Nebraska-Lincoln, the University of Southern California, and the Wharton School; and participants at the Chicago Junior Finance and Macro Conference, the Conference on Financial Frictions at Copenhagen Business School, and the Washington University Corporate Finance Conference for helpful discussions. We also thank Bilge Yilmaz for assistance in acquiring leveraged loan data. We gratefully acknowledge financial support from the Jacobs Levy Equity Management Center, the Rodney L. White Center, and the Wharton Financial Institutions Center. The views expressed herein are those of the authors and do not necessarily reflect the views of the National Bureau of Economic Research.

NBER working papers are circulated for discussion and comment purposes. They have not been peer-reviewed or been subject to the review by the NBER Board of Directors that accompanies official NBER publications.

(C) 2020 by Michael R. Roberts and Michael Schwert. All rights reserved. Short sections of text, not to exceed two paragraphs, may be quoted without explicit permission provided that full credit, including $\left({ }^{\circ}\right.$ notice, is given to the source. 
Interest Rates and the Design of Financial Contracts

Michael R. Roberts and Michael Schwert

NBER Working Paper No. 27195

May 2020, Revised January 2022

JEL No. E44,G21

\begin{abstract}
$\underline{\text { ABSTRACT }}$
We show that the partial response of loan rates to interest rate changes, referred to in the bank lending literature as "stickiness," is a feature of perfect capital markets. No-arbitrage models of credit risk are able to replicate empirical interest rate sensitivities. However, the widespread use of interest rate floors in the low-rate environment of the last decade is a result of risk-sharing and incentive considerations arising from market imperfections. Floors reallocate cash flows across states in a way that loan spreads cannot. They insure lenders against losses if rates fall, while mitigating borrower moral hazard if rates rise.
\end{abstract}

Michael R. Roberts

The Wharton School

University of Pennsylvania

3620 Locust Walk, \#2319

Philadelphia, PA 19104

and NBER

mrrobert@wharton.upenn.edu

Michael Schwert

Assistant Professor of Finance

The Wharton School

3620 Locust Walk-SHDH 2451

University of Pennsylvania

Philadelphia, PA 19104

schwert@wharton.upenn.edu

An online appendix is available at: http://www.nber.org/data-appendix/w27195 
This study examines how and why interest rates affect financial contracts using the leveraged loan market as a laboratory. We focus on the implications of interest rate variation for the loan pricing mechanism, while exploring other features (e.g., maturity and covenants) as a means of shedding further light on any observed relations. Our novel data set contains detailed information on contract terms and prices for a market that channels over $\$ 400$ billion to corporate borrowers annually. Lenders in this market cover a broad spectrum of investors including traditional commercial banks, insurance companies, asset managers (e.g., mutual funds, hedge funds), and collateralized loan obligations (CLOs).

We have two key findings. First, we show that frictionless models of credit risk (e.g., Merton (1974), Black and Cox (1976)) can quantitatively replicate the empirical interest rate sensitivity of loan rates. Consistent with previous research (e.g., Berger and Udell (1992)), we find that loan rates are "sticky," moving less than one-for-one with changes in interest rates. A one percentage point decrease in the level of interest rates only results in a 75 basis point (bp) reduction in loan rates, due to a 25 bp increase in loan spreads. We also show that loan rates are stickier for riskier borrowers. For instance, B-rated loan spreads increase by 35 bps in response to a one percentage point decrease in interest rates, whereas investment-grade-rated loan spreads increase by 14 bps. We reproduce both of these empirical facts in calibration exercises using the Merton (1974) model, which values risky debt in frictionless markets.

Theoretically, lower interest rates increase default risk, and therefore credit spreads, by reducing asset growth and raising the discounted value of expected default losses. This intuition is well understood in the corporate bond literature (e.g., Longstaff and Schwartz (1995), Duffee (1998), Collin-Dufresne, Goldstein, and Martin (2001)), which has found a negative correlation between bond credit spreads and risk-free rates. However, this same relation in loans has been attributed to a variety of market imperfections including information asymmetry (Berger and Udell (1992), Santos and Winton (2008), Schenone (2010), Botsch and Vanasco (2019), Demiroglu, James, and Velioglu (2021)), incomplete contracts (Fried 
and Howitt (1980), Rajan (1992)), imperfect competition (Drechsler, Savov, and Schnabl (2017)), leverage constraints (Wang (2020)), and behavioral biases (Dougal et al. (2015)). In contrast to these studies, we show that loan rate stickiness is an inherent feature of perfect capital markets and that existing models of credit risk quantitatively characterize this empirical relation surprisingly well.

Second, we show that the widespread introduction of interest rate floors in the lowrate period after the financial crisis is due to a combination of risk-sharing and incentive considerations. Before 2009, fewer than 5\% of loans contain an interest rate floor. By 2020, over $80 \%$ of loans have floors, which are responsible for approximately $8 \%$ of aggregate interest expense in our sample since 2010. In perfect capital markets, interest rate floors are irrelevant because lenders can increase the loan spread to replicate the value of any additional expected cash flows that would be realized from the presence of a floor. That is, there always exists a value-equivalent adjustment to the spread that would make both contracting parties indifferent between the inclusion of a floor and a higher credit spread.

The rationale for interest rate floors stems from their ability to reallocate cash flows across states of nature - from high to low interest rate environments. This reallocation accomplishes two goals, beginning with lenders' demand for insurance. All else equal, declining interest rates lead to lower interest expense and stronger financial health for borrowers, but decreasing margins and weaker financial health for commercial banks (e.g., Drechsler, Savov, and Schnabl (2017), Wang (2020)) that arrange leveraged loans. Consistent with this intuition, a one percentage point decline in interest rates is associated with an $8 \%$ increase in the probability of including a floor. However, this effect is most pronounced for institutional term loans that are funded mainly by CLOs (Standard \& Poor's (2020)). CLOs are funded by floating-rate bonds with long maturities and are not subject to the reduction in deposit spreads that constrains banks when rates are low.

Nevertheless, we show that insurance demand by banks, which along with insurance companies are the primary investors in CLO debt tranches (DeMarco, Liu, and Schmidt- 
Eisenlohr (2020), Foley-Fisher, Heinrich, and Verani (2021)), affects the design of CLO tranches and in turn, the design of leveraged loans. Using hand-collected data, we show that the increasing trend of interest rate floors in syndicated loans is met by a similar trend in CLO debt tranches. To complete the picture, we also show that the difference in the average level of LIBOR floors in CLO debt tranches (0\%) and in the loans comprising CLO collateral pools $(1 \%)$ results in additional cash flows to CLO equity holders and managers. Interest rate floors in loans therefore satisfy the profit motives of CLO managers and the demand by banks for insurance against negative rates.

In addition to their insurance function, floors mitigate moral hazard problems (e.g., Jensen and Meckling (1976)), which are increasing in borrowers' interest expense, all else equal. Specifically, floors permit lower loan spreads, which reduce loan coupon rates conditional on a rise in interest rates after issuance. Several pieces of evidence support this conclusion. First, the probability of including a floor is higher for less creditworthy borrowers. Further, this relation is amplified when the yield curve steepens, reflecting expectations of rising short-term interest rates. Finally, lenders are more likely to maintain strong covenant protections as expectations of future interest rates rise. In sum, these findings show that lenders are more likely to include a floor, increase the level of the floor, and maintain stronger covenant protection when moral hazard is of greatest concern - among riskier borrowers when interest rates are expected to rise.

Our first finding bridges two closely related, but largely independent, literatures, which include several papers referenced above. Studies of bank lending focus on the implications of market imperfections for loan pricing and other aspects loan contracts 1 In contrast, studies

\footnotetext{
${ }^{1}$ In addition to the aforementioned papers on loan pricing, a number of studies investigate particular aspects of corporate debt contracts including: pricing (e.g., Asquith, Beatty, and Weber (2005), Drucker and Puri (2009), Berg, Saunders, and Steffen (2016)), maturity (e.g., Flannery (1986), James (1987), Stohs and Mauer (1996), Demirguc-Kunt and Maksimovic (1999), Fan, Titman, and Twite (2012), Li, Loutskina, and Strahan (2021)), collateral (e.g., Benmelech and Bergman (2008), Benmelech (2009)), and covenants (e.g., Smith and Warner (1979), Malitz (1986), Berlin and Mester (1992), Bradley and Roberts (2015), Becker and Ivashina (2017), Green (2018), Berlin, Nini, and Yu (2020), Prilmeier and Stulz (2020)). Recent work in the macrofinance literature examines the interaction between debt contracts and the transmission of economic shocks (e.g., Chodorow-Reich and Falato (2020), Greenwald (2019)) and the effects of low rates on bank lending (e.g., Balloch and Koby (2020), Wang et al. (2020)).
} 
of bond credit spreads emphasize no-arbitrage models of credit risk, many of which do not rely on market imperfections. The ability of a simple, perfect markets model, such as Merton (1974), to explain the relation between loan spreads and interest rates suggests that it is not a straw-man null hypothesis for empirical studies of loan rates.

However, our second finding exposes the limitations of the perfect-markets null hypothesis and is related to prior research by Cohen, Lee, and Stebunovs (2016). These authors argue that the growing share of nonbank lenders targeting nominal yields has motivated a corresponding growth of interest rate floors. Our evidence is consistent with their conclusion, but our inferences are broader, highlighting the risk-sharing and incentive motives for nonbank and bank investors in these loans. We also argue that the distinction between banks and nonbanks is less clear when one considers the ultimate investor. In a similar vein, Arscott (2018) shows that interest rate floors are an economically important source of interest, driven by banks' preference for fixed-rate assets in low rate environments to cover fixed costs. We show that this is only part of the rationale for floors, which also serve to limit moral hazard.

The remainder of the paper is organized as follows. Section 1 describes the construction of the sample. Section 2 presents evidence on the relation between interest rates and loan terms. Section 3 explores the economic mechanisms underlying these results. Section 4 concludes.

\section{Data}

We rely on loan-level data from IHS Markit's Loan Pricing and Performance database, which we refer to as the IHS Markit database for brevity. These data are sourced from industry contacts and used by institutional investors in the leveraged (i.e., non-investment-grade) loan market to value portfolios and track the terms of outstanding loans. The IHS Markit

database contains between one-third to one-half of the approximately $\$ 3.5$ trillion of broadly 
syndicated loans outstanding (Bank of America Merrill Lynch (2019)) and nearly all of the $\$ 1.2$ trillion institutional segment of the loan market at the end of our sample period.2 ${ }^{2}$

A loan must satisfy the following criteria to be included in our analysis: U.S. dollar denominated, strictly positive loan principal, strictly positive maturity, nonnegative loan spread, and originated between January 1, 1997 and October 31, 2020. The sample is further limited to first-lien, secured loans to ensure comparability across contracts. Second-lien and unsecured loans excluded from the sample comprise less than ten percent of the IHS Markit database. We exclude a small number of debtor-in-possession loans and loans rated CCC+ or lower from our sample because the issuers of these loans are in default or at imminent risk of default at the time of issuance. Finally, we exclude a small number of other loan types including hybrid facilities, bridge loans, letters of credit, and notes.

Our analysis of credit risk models requires information on the borrower's capital structure. Most loans involve privately-held borrowers and are not subject to public disclosure, which means financial statements are not available for most borrowers in the sample. We obtain financial information for the public firms in our sample from Standard \& Poor's (S\&P) Capital IQ by merging the IHS Markit sample to Dealscan by the borrower name and loan characteristics (issue date, maturity, size) and applying the updated Dealscan-Compustat link from Chava and Roberts (2008). Details on the IHS Markit-Dealscan merge are provided in the Internet Appendix.

Lender financial information is obtained from the Center for Research in Security Prices (CRSP), S\&P Compustat, and Bank Holding Company FR Y-9C databases, accessed through Wharton Research Data Services. Macroeconomic time series are from the St. Louis Federal Reserve Economic Data (FRED) website. Information on the structure and pricing of CLOs comes from Bloomberg and the Creditflux CLO-i database. Finally, we obtain data on the composition of leveraged loan investors from S\&P Leveraged Commentary \& Data (LCD).

\footnotetext{
${ }^{2}$ We use the IHS Markit database instead of Thomson-Reuters Dealscan, which is commonly used in academic research, because the IHS Markit data include information on interest rate floors and cov-lite status. The Internet Appendix contains analysis showing that our results on loan spreads hold in Dealscan.
} 


\subsection{Sample Statistics}

Panel A of Figure 1 reports the aggregate amount of new originations in the U.S. leveraged loan market by tranche type. Tranche types correspond to an important segmentation in this market. Pro rata tranches, consisting of revolving lines of credit and term loan A facilities (Pro Rata TL in the figure), are held primarily by commercial banks. Lines of credit may be drawn down and repaid over the life of the loan, whereas term loans are fully drawn at origination. Pro rata term loans are typically repaid according to an amortization schedule, hence the "A" designation in term loan $\mathrm{A}^{3}$

Institutional tranches are structured for nonbank investors, such as collateralized loan obligations (CLOs), loan mutual funds, and hedge funds, though some commercial banks invest in these tranches as well. Institutional term loans, also called term loan B facilities, typically pay quarterly interest and a one-time principal ("bullet") payment at maturity.

The growth of the market over the sample period is apparent, as is the effect of the financial crisis in 2008 and 2009. Less obvious but still significant is the changing composition of loans over time. Institutional lending has outpaced pro rata lending in most years since 2004. The decline from 2019 to 2020 is due to the Covid-19 crisis and 2020 being a partial year, with our sample ending in October 2020.

Panel B of Figure 1 presents the temporal distribution of institutional tranche investors using data from S\&P LCD. CLOs are the most prominent investor type, responsible for the majority of funding since 2002. Hedge funds, loan mutual funds, and high-yield bond funds provide most of the remaining funding, with insurance and finance companies accounting for a small share.

Table 1 reports summary statistics for the sample of loans. The median loan has a stated maturity of 5 years and principal amount of $\$ 115$ million dollars. The median interest rate spread (loan spread, or just "spread") over LIBOR is 3.25\%. Two-thirds of loans in the

\footnotetext{
${ }^{3}$ We pool the pro rata and institutional loans throughout our main analysis to simplify the exposition. The Internet Appendix provides supplementary results showing that our main findings are qualitatively similar in both segments of the market. Where differences do exist, we discuss them below.
} 
sample are non-rated, and the vast majority of the remaining loans are non-investment-grade rated, in the $\mathrm{BB}$ and $\mathrm{B}$ categories. This composition reflects the data provider's focus on the "leveraged" (i.e., non-investment-grade) segment of the syndicated loan market.

Over one-third of loans contain a LIBOR floor. The median floor is set at $1 \%$, but the range spans from zero to over 5\%. Because LIBOR floors play a prominent role in our analysis, it is worthwhile to explain their implications for calculating loan interest. Without a floor, the coupon rate is computed as the sum of a base interest rate that varies over time (e.g., LIBOR) and a loan spread that is fixed at issuance $4^{4}$ Floors place a lower bound on the base rate, effectively converting the loan to a fixed-rate instrument when the base rate is below the floor. For example, suppose the loan spread is $3 \%$ and the level of the floor is $2 \%$. If LIBOR is $1 \%$, then the floor binds and the annualized coupon rate is $5 \%$ (3\% spread plus the $2 \%$ floor). If instead LIBOR is $4 \%$, then the floor is not binding and the coupon rate is $7 \%$ (3\% spread plus the $4 \%$ LIBOR).

A small fraction, 9\%, of loans in our sample, are classified as covenant-lite. This contract provision is concentrated in institutional tranches issued since the financial crisis and indicates relatively weak creditor protections. More precisely, covenant-lite loans eschew maintenance covenants, which are violated if the borrower breaches a specified financial threshold (e.g., debt-to-EBITDA ratio) for any reason, in favor of incurrence covenants which are breached only when corrective action is not undertaken. See Becker and Ivashina (2017), Berlin, Nini, and Yu (2020), and Prilmeier and Stulz (2020) for more details on covenant-lite loans.

\section{Interest Rates and Contract Terms}

Figure 2 presents a first look at the relation between interest rates and average contract terms over the sample period. Our goal with these figures is to provide an unobstructed view of the

\footnotetext{
${ }^{4}$ Some loan spreads vary according to a predetermined schedule linking the spread to a borrower risk metric, such as credit ratings or leverage. Although the IHS Markit database does not include information on these performance pricing measures, they are present in one-fifth of loans in Dealscan.
} 
data to shed light on potential associations between contract terms and interest rates. We focus on three-month LIBOR because it is the most salient rate, as the benchmark interest rate for virtually all of the loans in our sample. Unreported results using the three-month Treasury bill rate are quantitatively similar, which is unsurprising given the two rates have a correlation of 0.98 .

Several patterns in Figure 2 stand out. Loan spreads appear to be negatively correlated with LIBOR, though much of the variation in this series is concentrated around the Great Recession. The presence and level of LIBOR floors appear to be weakly negatively correlated with LIBOR. More pronounced in these series are the trends. Though present as early as 2002, the market share of loans with LIBOR floors increased dramatically from less than 5\% in 2008 to over $80 \%$ in 2020. During that same period, average floor levels decreased from over $3 \%$ to less than $0.75 \%$. Turning attention to nonprice terms, loan maturity appears to be positively correlated with LIBOR, while covenant-lite status follows a similar trend to LIBOR floor inclusion but on a smaller scale.

Though informative, the plots raise more questions than they answer. Are omitted factors, such as other macroeconomic forces (e.g., aggregate productivity or demand) or variation in the composition of borrower and lenders, confounding the relations? Are other rates or features of the yield curve related to loan terms? The remainder of this section addresses these questions.

\subsection{Panel Regressions}

We answer the first question by estimating panel regressions of the following form:

$$
y_{i, b, l, t}=\alpha+\beta r_{t}+\gamma W_{t}+\delta X_{i, b, l, t}+\mu_{b}+\kappa_{l}+\varepsilon_{i, b l, t} .
$$

The indices denote loan $i$ to borrower $b$ arranged by lender(s) $l$ in calendar quarter $t$. The outcome variable $y_{i, b, l, t}$ corresponds to a contract term (e.g., spread, presence of a LIBOR 
floor), $r_{t}$ is three-month LIBOR, $W_{t}$ is a vector of macroeconomic control variables, $X_{i, b, l, t}$ is a vector of loan-level controls, $\mu_{b}$ and $\kappa_{l}$ are borrower and lender fixed effects, respectively, and $\varepsilon_{i, b, l, t}$ is the regression residual.

The goal of these regressions is to mitigate endogeneity concerns, primarily those arising from sample selection and omitted variables. Reverse causality is less of a concern as the leveraged loan market, while economically significant, is not large enough to cause variation in LIBOR or other interest rates (e.g., Treasuries). The fixed effects alleviate concerns that the composition of borrowers or lenders is changing over time in a manner that is correlated with credit supply or credit demand. Coupled with the control variables, $W_{t}$ and $X_{i, b, l, t}$, the fixed effects also mitigate omitted variables concerns by controlling for time-invariant determinants of credit supply and demand. Though not a solution to the omitted variables problem, the model in equation (1) is a useful starting point for isolating the relation between contract terms and LIBOR.

Table 2 presents estimates of equation (1). We estimate the model with fixed effects (Panel B) and without them (Panel A) to demonstrate the impact of changes in the composition of borrowers and lenders. The models used in both panels are otherwise identical. Indicators for loan credit ratings measure borrower credit risk. The log of loan principal proxies for borrower credit demand, as borrowers typically approach lenders with a predetermined funding need. Though there may be changes to the exact amount during the syndication process, most of the variation in loan principal is due to differences in funding requirements as opposed to equilibrium price changes. Indeed, Crawford, Pavanini, and Schivardi (2018) use loan principal as an exogenous variable in the context of small business lending. Indicators for loan type (line of credit vs. term loan) are included to hold constant fee structures and payment terms.

The macroeconomic controls include real gross domestic product (GDP) growth, a recession indicator, and the cyclically adjusted equity market price-to-earnings (CAPE) ratio from Robert Shiller's website. The first two variables measure the state of the economy while 
allowing for linear and nonlinear relations with contract terms. The recession indicator also alleviates the concern that any relations are isolated to the period surrounding the Great Recession. The CAPE ratio proxies for the cost of equity, an alternative source of financing, while also capturing aspects of the broader economic environment.

The attenuation in coefficient magnitudes observed when moving from Panel A (no fixed effects) to Panel B (fixed effects) suggests that a changing sample composition is partly responsible for the relations observed in Figure 2. However, all of the LIBOR coefficient estimates are economically and statistically significant in Panel B. A one percentage point increase in LIBOR is associated with a 25 bp decrease in average spread and an 8.2 percentage point decrease in the probability of a LIBOR floor being present in the contract. Conditional on a floor being present in the loan, a one percentage point increase in LIBOR is associated with a $9.6 \mathrm{bp}$ increase in the level of the floor.

The fourth column presents results for the spread equivalent of the LIBOR floor, if any, in the contract. This measure, referred to as "floor value" for brevity, is estimated using the Black (1976) model. In a world constrained only by the absence of arbitrage, the floor value is an estimate of how much higher spreads must be to compensate lenders for removing the LIBOR floor from the contract. Contracts that do not have a LIBOR floor have a floor value of zero. The LIBOR coefficient estimate implies that a one percentage point decrease in LIBOR is associated with a $3.3 \mathrm{bp}$ increase in the spread-equivalent value of the floor, or $11 \%$ of the standard deviation conditional on having a floor provision.

The fifth column aggregates the spread and floor value into one measure, which we refer to as "adjusted spread." This measure is the sum of the loan spread and the spread-equivalent value of the floor. As such, the coefficient estimates are, but for rounding error, the sum of the coefficient estimates from the spread and floor value regressions. The bottom line is that a one percentage point decrease in short-term interest rates corresponds to a 29 bp increase in loan spreads, accounting for the value of interest rate floors.

The last two columns present results for loan maturities and covenant-lite status to un- 
derstand how these nonprice terms are moving with respect to interest rates. Loan maturities are positively associated with interest rates, increasing by three months for each percentage point. The propensity of a loan to be classified as covenant-lite declines by 3.4 percentage points for a one percentage point increase in interest rates. This is a large effect relative to the fraction of loans designated as such (9.2\%).

Though not the focus of our study, we briefly note that the control variables in these regressions are strongly correlated with loan terms. All three macroeconomic controls are economically and statistically significantly related to each term, as are the loan rating indicators. We look more closely at the role of these indicators and borrower risk below.

\subsection{Term Structure Decomposition}

Now we turn to the second question posed above, which asks whether other interest rates might matter for loan terms. There is good reason to believe they should. Under the expectations hypothesis, long-term rates contain information about expected future shortterm rates. Therefore, they should affect the decisions of forward-looking borrowers and lenders. However, it is not obvious which rates should matter and how to disentangle their effects. Interest rates at different maturities are highly correlated.

To address this challenge, we turn to the term structure literature. Litterman and Scheinkman (1991) show that most of the information in interest rates can be distilled in the first three principal components (PCs), each of which captures a different feature of the yield curve. We replicate this analysis using daily zero-coupon Treasury yields from 1997 to 2020 (Gurkaynak, Sack, and Wright (2007)). Over this period, the first PC explains 94.2\% of the variation in the yield curve, while the first three PCs cumulatively explain over $99.8 \%$ of the variation.

Figure 3 displays the first three principal components. The results are consistent with previous studies. The first factor consists of strictly positive loadings, suggesting that shocks to this component affect all yields in a similar manner. Hence, this factor is referred to as 
the level factor. It coincides most closely with an interest rate level, such as the LIBOR regressor used in our previous analysis. The correlation between LIBOR and the first PC is 0.78 .

The second factor consists of negative loadings on the short end and positive loadings on the long end of the yield curve. Shocks to this factor affect different ends of the yield curve in opposite directions. Thus, this factor is referred to as the slope factor. The correlation between the second PC and the long-short spread (10-year yield minus 3-month yield) is 0.90. Economically, the second PC reflects expectations of future interest rates $5^{5}$

The third component has positive loadings on the very short-end and long-end of the curve, and negative loadings in the middle. This factor is referred to as curvature, and shocks to it correspond to a buckling of the yield curve. Litterman, Scheinkman, and Weiss (1988) show that this factor is correlated with interest rate volatility. However, the marginal contribution of this component to the total explanatory power of the PCs is negligible, an incremental $R^{2}$ of $0.3 \%$. Thus, we focus attention on the first two components and include a separate yield volatility measure in our analysis. ${ }^{6}$

Table 3 presents estimates of equation (1) in which we replace LIBOR with the first two PCs of the yield curve - level and slope - and a measure of yield volatility. The specifications in Panels A and B are otherwise identical to those in the corresponding panels of Table 2 . As before, we discuss the more conservative results in Panel B obtained from the fixed effects specification.

The level PC coefficients are quantitatively similar to the results based on LIBOR in Table 2. A one standard deviation upward shift in the yield curve is associated with a 52 bp decrease in spreads (versus a 54 bp decrease from a one standard deviation, or 2.15\%,

\footnotetext{
${ }^{5}$ The empirical evidence in support of the expectations hypothesis is mixed. For example, Campbell and Shiller (1991) find that when the term spread is high, long-term rates tend to fall but short-term rates tend to rise. Because leveraged loans are floating-rate instruments tied to short-term rates, this finding suggests that the expectations hypothesis is a plausible interpretation of the slope PC in our setting.

${ }^{6}$ We measure interest rate volatility with the MOVE Index. Developed by Merrill Lynch, this index is constructed from the implied volatilities for constant one-month at-the-money options on 2-year, 5-year, 10-year, and 30-year U.S. Treasuries. The MOVE Index measures market participants assessment of interest rate uncertainty, analogous to the VIX's measurement of equity value uncertainty.
} 
increase in LIBOR), a 23\% (18\%) decrease in the probability of including a floor, and a 34 bp (21 bp) increase in the level of the floor. In a similar fashion, the floor values, adjusted spreads, and nonprice contract terms (maturity, covenant-lite status) are strongly correlated with the level PC.

The slope PC coefficients provide more insight into the information contained in the yield curve that is not captured by LIBOR, notably expectations of future interest rates. The coefficient estimates show that the slope PC is positively associated with both loan spreads and the propensity to include a floor, and thus also with the floor value and adjusted spread. As expectations of future interest rates increase, loans become more expensive for borrowers. However, the magnitudes of the slope coefficients are smaller than those of the level, suggesting that interest rate expectations moderate the effects of the current interest rate environment.

Uncertainty about future interest rates, as captured by yield volatility, is also strongly correlated with price-related loan terms. Interest rate uncertainty is associated with higher loan spreads and floor levels, resulting in higher adjusted spreads. Put differently, uncertainty about future interest rates leads to discounted loan prices.

In sum, these findings demonstrate that different aspects of the yield curve are relevant for loan terms. LIBOR provides a reasonable reflection of the yield curve's level, but the slope and volatility of the yield curve contain information about future expectations and uncertainty in interest rates that appear to be relevant for the design of loan contracts.

\section{$3 \quad$ Why Interest Rates Matter for Contract Terms}

There are several potential explanations for the correlations between loan terms and interest rates described above. To shed light on these explanations, this section investigates the empirical implications of different theories of credit risk and bank lending. We pay close attention to non-overlapping implications in an attempt to discriminate among the theories. 


\subsection{No-Arbitrage Models of Credit Risk}

No-arbitrage models of credit risk are a natural starting point for any investigation into the pricing of risky debt. We focus attention on the Merton (1974) model because of its simplicity. There are no market imperfections in the Merton model, so it provides a null hypothesis akin to Modigliani and Miller (1958). The limitations of this model for matching corporate bond credit spreads are well documented (e.g., Huang and Huang (2012)), though still subject to debate (Feldhutter and Schaefer (2018), Bai, Goldstein, and Yang (2020)).

Merton (1974) assumes that the firm's value follows a geometric Brownian motion under the risk-neutral measure,

$$
d \ln V_{t}=\left(r-\frac{1}{2} \sigma^{2}\right) d t+\sigma d W_{t}^{Q}
$$

Suppose the firm has a zero-coupon loan outstanding with face value $K$ and $T$ years to maturity. The payoff to the loan is equivalent to a portfolio containing a risk-free bond and a short put option struck at the face value. Under this basic setup, the value of the loan is:

$$
D=V-\left[V \Phi\left(d_{1}\right)-K e^{-r T} \Phi\left(d_{2}\right)\right]
$$

where

$$
d_{1}=\frac{\ln (V / K)+\left(r+\frac{1}{2} \sigma^{2}\right) T}{\sigma \sqrt{T}}, \quad d_{2}=d_{1}-\sigma \sqrt{T} .
$$

The yield of the loan is $y=\frac{1}{T} \ln (K / D)$ because it is modeled as a zero-coupon instrument.

Because this model requires information on the borrower's capital structure, the analysis here uses the intersection of the IHS Markit, Dealscan, and Capital IQ databases, described in Section $11^{7}$ We calibrate asset volatility to the observed loan spread, instead of unlevering the borrower's equity volatility, to avoid the underestimation of credit spreads documented

\footnotetext{
${ }^{7}$ Specifically, we require the amount of first-lien secured loans outstanding after issuance for the face value of debt in the model. Schwert (2020) shows that the amount of junior debt outstanding is irrelevant to the pricing of first-lien loans in the basic Merton model without bankruptcy costs.
} 
by Huang and Huang (2012). To account for prepayment risk, time to maturity is set to an estimate of the loan's expected life, equal to the loan's contractual maturity times the sample average ratio of realized life to maturity for each credit rating. Finally, we bootstrap zero-coupon LIBOR rates from the interest rate swap curve to obtain a risk-free discount rate over the expected life of each loan 8

We estimate the model-implied interest rate sensitivity of credit spreads for each loan as follows. Baseline estimates are constructed using the empirical counterpart for each model parameter at the prevailing interest rate. We then recompute the model-implied spread by increasing and decreasing the interest rate parameter by $0.5 \%$. The difference in spreads is the model-implied sensitivity of loan spreads to a one percentage point increase in the level of interest rates.

Table 4 presents the empirical distribution of loan spread interest rate sensitivities estimated from the Merton model. The statistics are computed for the whole sample, as well as each loan rating category. Panel A is based on the intersection of IHS Markit, Dealscan, and Capital IQ, while Panel B interpolates the capital structure information by loan rating to cover the full IHS Markit sample.

Unconditionally, the average sensitivity in Panel B is -33 bps. In words, the Merton model generates a response of credit spreads to interest rate variation that dampens the effect of a change in interest rates on the overall loan rate. In the language of Berger and Udell (1992), loan interest rates are sticky, responding less than one-for-one with changes in risk-free interest rates. The estimates by loan rating reveal that loan rates become stickier as borrower credit risk increases. Riskier borrowers, as measured by loan rating, face larger decreases in spreads when interest rates rise. Consequently, interest expense is less responsive to interest rate variation for riskier borrowers.

The mechanism responsible for these results is the pricing of default risk. All else equal, lower interest rates increase the discounted value of losses borne by creditors in the event

\footnotetext{
${ }^{8}$ In the Internet Appendix, we show that the results are qualitatively similar if we change our assumptions about time to maturity and the risk-free rate.
} 
of default, which raises the credit spread. At the same time, lower interest rates reduce the growth rate of firm value, which increases the likelihood of default. Both effects are more pronounced for riskier firms, which have higher leverage or asset volatility in the model.

Figure 4 presents comparative statics underpinning this intuition. Panel A plots the credit spread as a function of the risk-free rate for different levels of leverage, showing that the negative relation between spreads and risk-free rates is more pronounced for firms with high leverage. Panel B presents similar patterns for different levels of asset volatility, holding leverage fixed.

How do the model-implied sensitivities compare to what we see in the data? The unconditional estimate of -33 bps is, perhaps surprisingly, close to the empirical spread (-25 bps) and adjusted spread (-29 bps) sensitivities presented in Panel B of Table 2, Empirical sensitivities conditional on borrower risk are estimated using the panel regression model in equation (1), augmented with interaction terms between LIBOR and loan credit rating indicators. The control variables include log issue size, GDP growth, a U.S. recession indicator, and fixed effects for loan type, credit rating, borrower industry, and lead arranger.

The estimation results are presented in Panel A of Table 5. The excluded rating category is investment-grade-rated loans. Focusing on the first column, the sensitivity of spreads to LIBOR is increasing in borrower risk. The spread sensitivity to interest rates of investmentgrade-rated loans is $-13.5 \mathrm{bps}$, compared to that of a BB-minus-rated loan, $-24.1 \mathrm{bps}$, or a B-minus-rated loan, -37.2 bps. The same sensitivities for adjusted spread are -15.3, -29.0, and -43.5 bps, respectively.

To ease comparisons with the implications from the Merton model, Panel A of Figure 5 plots the interest rate sensitivities by rating category for the adjusted spread, alongside the predictions from the Merton model ${ }^{9}$ The pattern is strikingly similar, inside the empirical confidence band for all but the B-rated loans, for which the difference is only 12 bps.

\footnotetext{
${ }^{9}$ This figure presents empirical sensitivities based on the same bootstrapped zero-coupon rates that are used as Merton model inputs. These sensitivities are quantitatively similar to the estimates reported in Table 5 , which are based on LIBOR.
} 
In sum, no-arbitrage models of credit risk provide a quantitatively consistent explanation for loan spread patterns observed in the data. The stickiness of loan interest rates, often attributed to a range of market imperfections, exists in a world without market imperfections ${ }^{10}$ However, credit risk models cannot explain why borrowers and lenders choose to include interest rate floors instead of further raising loan spreads when interest rates are low. Further, these models have nothing to say about the role played by lenders in the contracting process. The remaining sections explore these features of the data more closely.

\subsection{Banking Frictions}

Interest rate floors allow lenders to insure against interest rate risk. By converting floatingrate debt to fixed-rate debt below a certain threshold, floors also address concerns with fixed operating costs. Even if interest rate risk is perfectly hedged, the risk associated with fixed operating costs rises as interest rates (and interest income) decline. Floors ensure a minimum level of interest income no matter how far interest rates fall. The unconditional results in Tables 2 and 3 are consistent with this rationale. As interest rates decline, loans are more likely to incorporate interest rate floors.

Panel B of Table 5 explores this implication. The regression is similar to that found in Panel A and discussed above, with the credit rating indicators replaced by lender income gap indicators representing terciles of the income gap distribution. The income gap measures the difference between the values of assets and liabilities that mature or reprice within one year (Gomez et al. (2021)). In doing so, this measure captures the risk exposure of bank profits to interest rate fluctuations. When interest rates increase, both interest income and expense increase. If a bank's income gap is large, the increase in interest income is greater than interest expense and the bank is better off. When interest rates decrease, banks with a large income gap will be worse off as the decline in interest income is larger than the decline

\footnotetext{
${ }^{10}$ Theories generating loan rate stickiness via market imperfections include those predicated on adverse selection (e.g., Stiglitz and Weiss (1981) and Dell'Ariccia and Marquez (2006)), moral hazard (Rajan (1992)), imperfect competition (Drechsler, Savov, and Schnabl (2017)), and leverage constraints (Wang (2020)).
} 
in interest expense. Banks with income gaps close to zero are less sensitive to interest rate variation because it has similar effects on interest income and expense.

The results in Panel B of Table 5 show that loan spread sensitivities are increasing in the income gap. When interest rates decline, spreads increase by more for lenders with larger income gaps. This behavior is consistent with a demand for insurance, but only provides effective insurance if lending relationships are persistent ${ }^{11}$ However, we don't see similar results for the presence of an interest rate floor or the floor level.

As an alternative lens on this issue, we exploit variation in lender types. As discussed earlier, pro rata tranches are held primarily by commercial banks, while institutional tranches are funded by nonbank intermediaries. Commercial banks have "deposit franchises," to use the language of Drechsler, Savov, and Schnabl (2021), which benefit from imperfect local competition. In contrast, nonbank intermediaries raise funds from competitive market-based sources. Since commercial banks suffer from shrinking deposit spreads when interest rates fall (Drechsler, Savov, and Schnabl (2017)), we predict that they will be more likely than nonbank lenders to demand interest rate floors.

Panel $\mathrm{C}$ of Table 5 explores this hypothesis by interacting LIBOR with an indicator for institutional term loans. The LIBOR coefficients capture the interest rate sensitivity of loan terms for pro rata tranches, our empirical proxy for commercial bank loans. The coefficient estimates are economically and statistically significant, indicating that loans from commercial banks have sticky rates and are more likely to include floors when rates are low.

In contrast to our prediction, institutional tranches exhibit even stronger responses to interest rate variation than pro rata tranches. The interaction coefficient estimates are all negative and statistically significant. For example, a one percentage point decline in interest rates is associated with a $23 \mathrm{bp}$ increase in spreads for pro rata tranches, and a $27 \mathrm{bp}$ increase for institutional tranches. Nonbank lenders are also twice as likely as commercial banks to include an interest rate floor when interest rates decline.

\footnotetext{
${ }^{11}$ In the absence of relationship frictions, borrowers would switch to lenders with a smaller income gap when rates decline, avoiding the increase in spreads.
} 
These nonbank intermediaries have neither deposit franchises nor market power over funding sources. On the contrary, the funding sources for these intermediaries are highly competitive (e.g., securities issuance, repurchase agreements). More broadly, while theories predicated on frictions unique to banks (e.g., Fried and Howitt (1980), Sharpe (1990), Dreschler et al. (2020)), Wang (2020)) are consistent with our findings for pro rata tranches, they do little to explain the preference for these contract features among nonbank lenders.

\subsection{Nonbank Lenders}

As shown in Panel B of Figure1, CLOs provide the majority of funding for institutional loans. These securitization vehicles channel interest and principal from a portfolio of leveraged loans to investors in a prioritized set of claims (Benmelech and Dlugosz (2009)). While CLOs cater to a wide array of investors, the most important are arguably those who fund the senior and equity tranches. Equity capital is required to initiate a CLO and senior tranches provide the majority of funding, approximately two-thirds for the average CLO (Cordell, Roberts, and Schwert (2021)). Thus, to understand the role of interest rate floors in institutional loans, one must understand the incentives of these two groups of investors.

The primary investors in CLO senior notes are banks and insurance companies (DeMarco, Liu, and Schmidt-Eisenlohr (2020), Foley-Fisher, Heinrich, and Verani (2021)). Therefore, banks are indirectly exposed to risky loans through CLOs, bearing less risk as a result of the seniority provided by CLO tranching. Because CLO debt tranches are floating-rate instruments, changes in interest rates are passed on to the banks, which at first glance seems at odds with the desire of banks to hedge against low interest rates as suggested by Drechsler, Savov, and Schnabl (2017) and Wang (2020).

However, using data collected from Bloomberg, we find that CLO senior notes also incorporate LIBOR floors. Figure 6 presents two quarterly time series. The first is the fraction of newly issued CLOs with a LIBOR floor covering the senior tranche. The second, for comparison, is the fraction of institutional term loans with a LIBOR floor. CLOs began 
incorporating LIBOR floors before institutional loans and both lines trend upwards, though more consistently for loans. An inspection of CLO indentures reveals no covenants explicitly requiring leveraged loans in the collateral pool contain a LIBOR floor. That is, CLO debt investors do not appear to require the vehicles only purchase loans containing floors.

Rather, LIBOR floors in leveraged loans are more likely a consequence of demand from CLO managers and equityholders for insurance against their state-contingent fixed-rate claims (i.e., debt tranches with floors) and their profit-seeking motives. To illustrate the effect of LIBOR floors on CLO equity yields, we construct a simulation based on our sample of loans and data on CLO structures from CLO-i. We compute the principal value-weighted loan spread, level of LIBOR floor, CLO leverage, and CLO tranche coupon rates in each year with available data on CLOs. Then we compute the initial equity yield, equal to the difference between the coupons on the loan pool and the coupons on the CLO tranches divided by the principal amount of the equity tranche, under three scenarios. The first uses the observed level of loan spreads and floors to compute loan coupon rates. The second uses the same loan spreads and assumes no loans have floors. The third also assumes no loans have floors, but adjusts the loan spread upwards by the spread-equivalent value of the floor. The Internet Appendix provides additional detail on these calculations.

Figure 7 presents the results of this exercise. We focus on the period after the financial crisis because floors have a negligible effect in the pre-crisis period and there is no issuance during the crisis. The pricing of loans and CLOs in our sample period is such that an equity investor in the typical CLO earns a current yield between $15 \%$ and $30 \%$.12 LIBOR floors in leveraged loans, which are set at an average level of $1 \%$, increase the equity yield by raising the level of coupons received by the collateral pool relative to the coupons paid on CLO debt tranches, which have no floor or a floor set uniformly at zero. The effect of LIBOR floors is to increase the CLO equity yield by between two and four percentage points from 2012 to

\footnotetext{
${ }^{12}$ The high return to CLO equity is attributable to 10-to- 1 leverage and the gap between the coupon rates of syndicated loans in the collateral pool and the tranche securities issued by the securitization vehicle. See Cordell, Roberts, and Schwert (2021) for evidence on the investment performance of CLOs.
} 
2015. The direct impact of floor inclusion disappears in 2016, when the typical floor is not binding, but the spread adjustment still has an effect due to the floor's option value.

\subsection{Moral Hazard}

A remaining question is why lenders that are concerned about low interest rates prefer to include interest rate floors instead of raising loan spreads. Interest rate floors reallocate cash flows from high to low interest rate states of the world, which accomplishes two goals. The first, as we discuss above, is that floors provide insurance to lenders when interest rates are low and boost yields to equity investors in CLOs. The second, which we explore here, is that floors mitigate moral hazard when interest rates are high. The first goal can be accomplished by raising loan spreads, but the second cannot.

High interest rates increase interest expense for borrowers and, all else equal, borrower default risk. Increasing default risk exacerbates incentive conflicts between borrowers and lenders (Jensen and Meckling (1976)). By reallocating cash flows from high interest rate environments to low interest rate environments, floors can mitigate moral hazard problems. We test this hypothesis by exploring several implications.

Table 6 presents estimates of regressions similar to the second column of Table 3 . The dependent variable is an indicator for the presence of a floor. We present the results from several fixed-effects specifications indicated at the bottom of the table. Since our focus is not on the interest rate relation, we control for aggregate trends using time fixed effects. The results show that the probability of including a floor is increasing in borrower credit risk. Thus, for riskier borrowers with greater potential for moral hazard, we see a greater prevalence of interest rate floors, as well as stickier loan spreads (recall Table 5 Panel A).

Table 7 explores the link between contract features and expectations of future interest rates by interacting the second principal component of the yield curve (Slope PC), a proxy for expectations of future interest rates, with loan rating indicator variables. Panel A shows that as expectations of future interest rates increase, the probability of including a floor increases 
by more for riskier borrowers. Relative to investment-grade loans, BB-rated loans are $4 \%$ more likely to include a floor, and B-rated loans are 7\% more likely. Likewise, investmentgrade loans are approximately $3 \%$ less likely to be covenant-lite when expectations of future interest rates increase by $1 \%$, while B-rated loans are approximately $9 \%$ less likely. When expectations of future interest rates increase, lenders demand stronger covenant protections, especially from riskier borrowers.

In sum, these findings suggest that lenders and borrowers structure loan contracts to mitigate the effects of moral hazard driven by expected future rate changes. Lenders are wary of imposing high interest rates on riskier borrowers, so they are more likely to reallocate cash flows from high-rate to low-rate states for riskier borrowers, and they are less likely to concede control rights when interest rates are expected to increase.

\section{Conclusion}

Interest rates play an important role in shaping loan terms. Somewhat surprisingly, noarbitrage models of credit risk do a good job of matching observed loan spreads' responses to interest rate variation. This implies that sticky loan rates, a phenomenon thought to reflect a variety of market imperfections, are an inherent feature of perfect capital markets.

Nevertheless, loan contracts contain features that are likely driven by market imperfections. Imperfect competition, information asymmetry, and contracting frictions are additional forces necessary to understand the the cash flows governed by loan contracts.

While we have made progress in understanding the relation between interest rates and the design of financial contracts, many questions remain. For instance, does the endogenous response of contracts to interest rate variation help to explain the lack of compelling evidence relating corporate investment to the cost of capital? And, how should one measure the cost of capital when it is determined by a complex, state-contingent pricing mechanism? We look forward to future research that addresses these and related questions. 


\section{References}

Arscott, Robert, 2018, LIBOR floors in leveraged loans, Working paper, Syracuse University.

Asquith, Paul, Anne Beatty, and Joseph Weber, 2005, Performance pricing in bank debt contracts, Journal of Accounting and Economics 40, 101-128.

Bai, Jennie, Robert Goldstein, and Fan Yang, 2020, Is the credit spread puzzle a myth? Journal of Financial Economics 137, 297-319.

Balloch, Cynthia, and Yann Koby, 2020, Low rates and bank loan supply: Theory and evidence from Japan, Working paper, London School of Economics.

Bank of America Merrill Lynch, 2019, Corporate loan primer: Understanding the evolving credit ecosystem.

Becker, Bo, and Victoria Ivashina, 2017, Covenant-lite contracts and creditor coordination, Riksbank Research Paper Series No. 149.

Benmelech, Efraim, 2009, Asset salability and debt maturity: Evidence from nineteenth-century American railroads, Review of Financial Studies 22, 1545-1584.

Benmelech, Efraim, and Nittai K. Bergman, 2008, Liquidation values and the credibility of financial contract renegotiation: Evidence from U.S. airlines, Quarterly Journal of Economics 123, 16351677.

Benmelech, Efraim, and Jennifer Dlugosz, 2009, The alchemy of CDO credit ratings, Journal of Monetary Economics 56, 617-634.

Berg, Tobias, Anthony Saunders, and Sascha Steffen, 2016, The total cost of corporate borrowing in the loan market: Don't ignore the fees, Journal of Finance 71, 1357-1392.

Berger, Allen N., and Gregory F. Udell, 1992, Some evidence on the empirical significance of credit rationing, Journal of Political Economy 100, 1047-1077.

Berlin, Mitchell, and Loretta J. Mester, 1992, Debt covenants and renegotiation, Journal of Financial Intermediation 2, 95-133.

Berlin, Mitchell, Greg Nini, and Edison Yu, 2020, Concentration of control rights in leveraged loan syndicates, Journal of Financial Economics 137, 249-271.

Black, Fischer, 1976, The pricing of commodity contracts, Journal of Financial Economics 3, 167179.

Black, Fischer, and John C. Cox, 1976, Valuing corporate securities: Some effects of bond indenture provisions, Journal of Finance 31, 351-367.

Botsch, Matthew, and Victoria Vanasco, 2019, Learning by lending, Journal of Financial Intermediation 37, 1-14.

Bradley, Michael, and Michael R. Roberts, 2015, The structure and pricing of corporate debt covenants, Quarterly Journal of Finance 5, 1-37. 
Campbell, John and Robert Shiller, 1991, Yield spreads and interest rate movements: A bird's eye view, Review of Economic Studies 58, 498-514.

Chava, Sudheer, and Michael R. Roberts, 2008, How does financing impact investment? The role of debt covenants, Journal of Finance 63, 2085-2121.

Chodorow-Reich, Gabriel, and Antonio Falato, 2020, The loan covenant channel: How bank health transmits to the real economy, Journal of Finance, forthcoming.

Cohen, Gregory J., Seung Jung Lee, and Viktors Stebunovs, 2016, Limits to monetary policy transmission at the zero lower bound and beyond: The role of nonbanks, Working paper, Federal Reserve Board of Governors.

Collin-Dufresne, Pierre, Robert S. Goldstein, and Spencer Martin, 2001, The determinants of credit spread changes, Journal of Finance 56, 2177-2207.

Cordell, Larry, Michael R. Roberts, and Michael Schwert, 2021, CLO performance, Journal of Finance, forthcoming.

Crawford, Gregory, Nicola Pavanini, and Fabiano Schivardi, 2018, Asymmetric information and imperfect competition in lending markets, American Economic Review 108, 1659-1701.

Dell'Ariccia, Giovanni, and Robert Marquez, 2006, Lending booms and lending standards, Journal of Finance 61, 2511-2546.

DeMarco, Laurie, Emily Liu, and Tim Schmidt-Eisenlohr, 2020, Who owns U.S. CLO securities?An update by tranche, FEDS Notes, Federal Reserve Board of Governors, June 25, 2020.

Demirguc-Kunt, Asli, and Vojislav Maksimovic, 1999, Institutions, financial markets, and firm debt maturity, Journal of Financial Economics 54, 295-336.

Demiroglu, Cem, Christopher M. James, and Guner Velioglu, 2021, Why are commercial loan rates so sticky? The effect of private information on loan spreads, Journal of Financial Economics, forthcoming.

Dougal, Casey, Joseph Engelberg, Christopher A. Parsons, and Edward D. van Wesep, 2015, Anchoring on credit spreads, Journal of Finance 70, 1039-1080.

Drechsler, Itamar, Alexi Savov, and Philipp Schnabl, 2017, The deposits channel of monetary policy, Quarterly Journal of Economics 132, 1819-1876.

Drechsler, Itamar, Alexi Savov, and Philipp Schnabl, 2021, Banking on deposits: Maturity transformation without interest rate risk, Journal of Finance 76, 1091-1143.

Drucker, Steven, and Manju Puri, 2009, On loan sales, loan contracting, and lending relationships, Review of Financial Studies 22, 2835-2872.

Duffee, Gregory R., 1998, The relation between Treasury yields and corporate bond yield spreads, Journal of Finance 53, 2225-2241.

Fan, Joseph P.H., Sheridan Titman, and Garry Twite, 2012, An international comparison of capital structure and debt maturity choices, Journal of Financial and Quantitative Analysis 47, 23-56. 
Feldhütter, Peter and Stephen M. Schaefer, The Myth of the Credit Spread Puzzle, The Review of Financial Studies 31, 2897-2942.

Flannery, Mark J., 1986, Asymmetric information and risky debt maturity choice, Journal of Finance 41, 19-37.

Foley-Fisher, Nathan, Nathan Heinrich, and Stephane Verani, 2021, Are life insurers the new shadow banks? Working paper, Federal Reserve Board of Governors.

Fried, Joel, and Peter Howitt, 1980, Credit rationing and implicit contract theory, Journal of Money, Credit, and Banking 12, 471-487.

Gomez, Matthieu, Augustin Landier, David Sraer, and David Thesmar, 2021, Banks' exposure to interest rate risk and the transmission of monetary policy, Journal of Monetary Economics 117, 543-570.

Green, Daniel, 2018, Corporate refinancing, covenants, and the agency cost of debt, Working paper, Harvard Business School.

Greenwald, Daniel, 2019, Firm debt covenants and the macroeconomy: The interest coverage channel, Working paper, MIT Sloan.

Gurkaynak, Refet S., Brian Sack, and Jonathan H. Wright, 2007, The U.S. Treasury yield curve: 1961 to the present, Journal of Monetary Economics 54, 2291-2304.

Huang, Jing-Zhi, and Ming Huang, 2012, How much of the corporate-Treasury yield spread is due to credit risk? Review of Asset Pricing Studies 2, 153-202.

James, Christopher, 1987, Some evidence on the uniqueness of bank loans, Journal of Financial Economics 19, 217-235.

Jensen, Michael, and William Meckling, 1976, Theory of the firm: Managerial behavior, agency costs, and ownership structure, Journal of Financial Economics 3, 305-360.

Li, Lei, Elena Loutskina, and Philip E. Strahan, 2021, Deposit market power, funding stability, and long-term credit, Working paper, Federal Reserve Board of Governors.

Litterman, Robert, and Jose Scheinkman, 1991, Common factors affecting bond returns, Journal of Fixed Income 1, 54-61.

Litterman, Robert, Jose Scheinkman, and Laurence Weiss, 1988, Volatility and the yield curve, Technical report, Goldman Sachs \& Co.

Longstaff, Francis A., and Eduardo S. Schwartz, 1995, A simple approach to valuing risky fixed and floating rate debt, Journal of Finance 50, 789-819.

Malitz, Ileen, 1986, On financial contracting: The determinants of bond covenants, Financial Management 15, 18-25.

Merton, Robert C., 1974, On the pricing of corporate debt: The risk structure of interest rates, Journal of Finance 29, 449-470.

Modigliani, Franco and Merton Miller, 1958, The Cost of Capital, Corporation Finance and the Theory of Investment, American Economic Review 48, 261-297. 
Prilmeier, Robert, and René M. Stulz, 2020, Securities laws, bank monitoring, and the choice between cov-lite loans and bonds for highly levered firms, Working paper, Tulane University.

Rajan, Raghuram G., 1992, Insiders and outsiders: The choice between informed and arm's-length debt, Journal of Finance 47, 1367-1400.

Santos, Joao A.C., and Andrew Winton, 2008, Bank loans, bonds, and information monopolies across the business cycle, Journal of Finance 63, 1315-1359.

Schenone, Carola, 2010, Lending relationships and information rents: Do banks exploit their information advantages? Review of Financial Studies 23, 1149-1199.

Schwert, Michael, 2020, Does borrowing from banks cost more than borrowing from the market? Journal of Finance 75, 905-947.

Sharpe, Steven A., 1990, Asymmetric information, bank lending, and implicit contracts: A stylized model of customer relationships, Journal of Finance 45, 1069-1087.

Smith, Clifford W., and Jerold B. Warner, 1979, On financial contracting: An analysis of bond covenants, Journal of Financial Economics 7, 117-161.

Standard \& Poor's, 2020, LCD's Quarterly Leveraged Lending Review: 2Q 2020.

Stiglitz, Joseph E., and Andrew Weiss, 1981, Credit rationing in markets with imperfect information, American Economic Review 71, 393-410.

Stohs, Mark H., and David C. Mauer, 1996, The determinants of corporate debt maturity structure, Journal of Business 69, 279-312.

Wang, Olivier, 2020, Banks, low interest rates, and monetary policy transmission, Working paper, New York University.

Wang, Yifei, Toni M. Whited, Yufeng Wu, and Kairong Xiao, 2020, Bank market power and monetary policy transmission: Evidence from a structural estimation, Working paper, University of Michigan.

Zhang, X. Frank, 2006, Information uncertainty and stock returns, Journal of Finance 61, 105-137. 
Figure 1: Leveraged Loan Originations

This figure reports aggregate issuance volumes in the leveraged loan market by segment and the breakdown of investor types in the institutional segment. Panel A reports the annual volume of U.S. dollar leveraged loan issuance by loan type. The sample is restricted to originations between January 1997 and October 2020, inclusive, with nonmissing data for the loan spread, maturity, and size of the loan. Panel B reports the market shares in the institutional segment of various types of nonbank investor. Data on investor shares are from S\&P Leveraged Commentary \& Data from 2002 to 2020.

\section{Panel A: Annual Amount of Loan Originations}

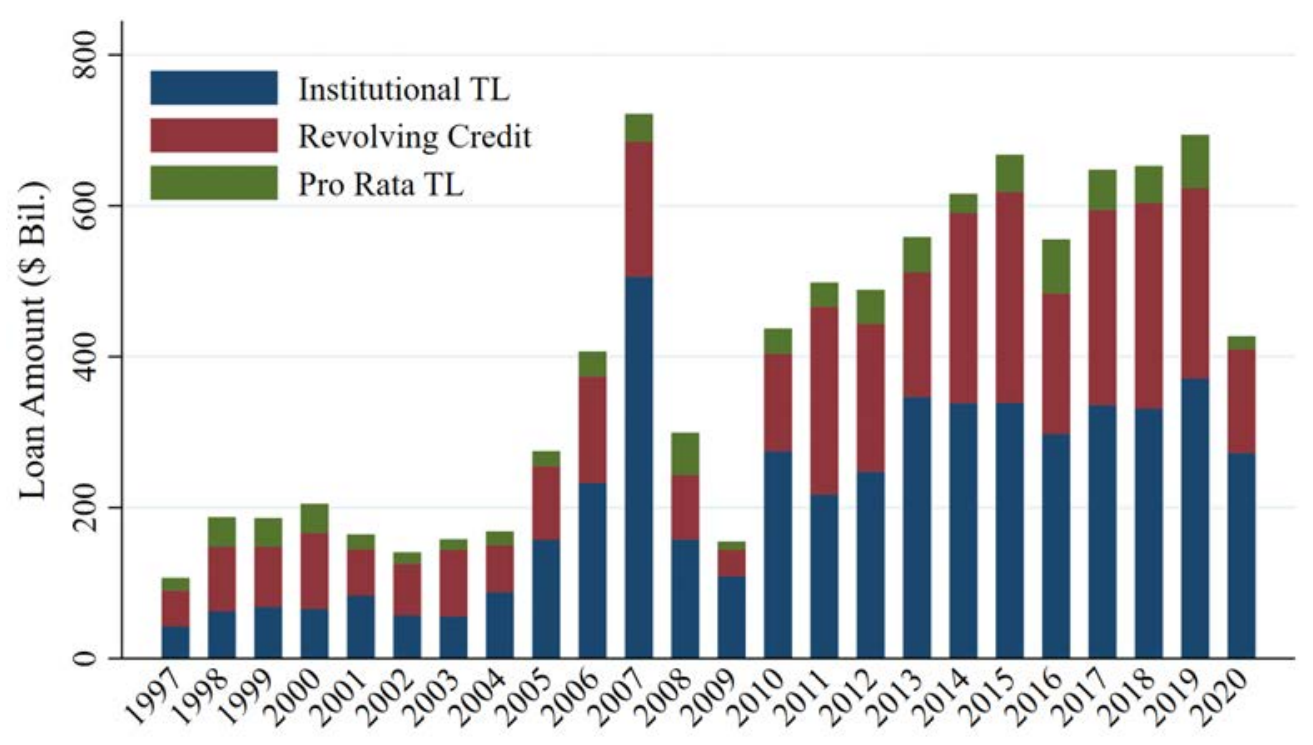

Panel B: Annual Investor Shares in the Institutional Segment

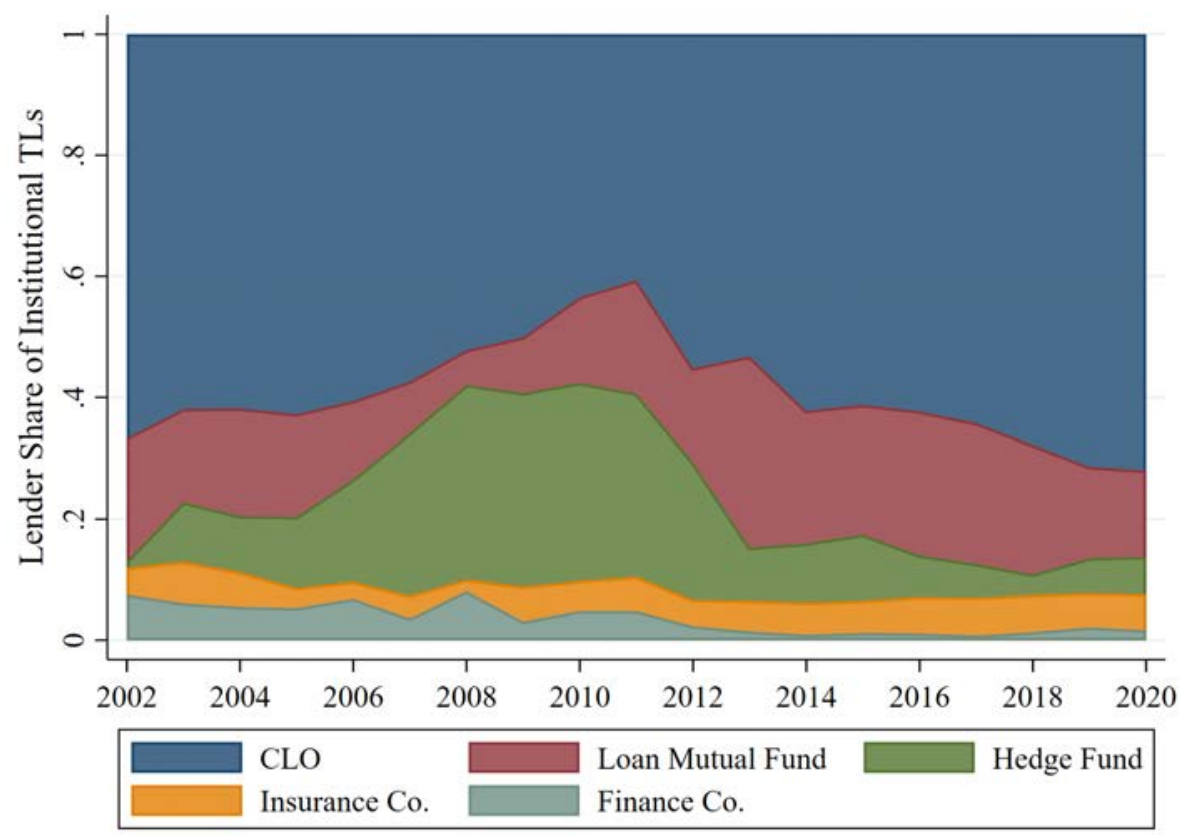


Figure 2: Interest Rates and Contract Terms

This figure presents time-series plots of contract terms against short-term interest rates. Each panel presents two quarterly time series. The dashed red line presents the average three-month LIBOR rate for the quarter. The solid blue line corresponds to a component of the contract pricing mechanism, expressed as an average weighted by loan size. For ease of presentation, each quarterly series is presented as a moving average with one-half weight on the current quarter and one-quarter weight on each of the neighboring quarters.

Panel A: Loan Spread

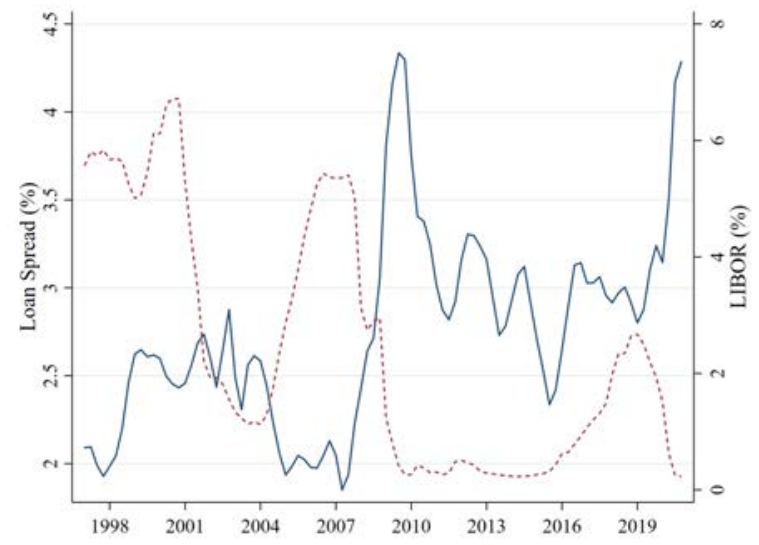

Panel C: Level of LIBOR Floor

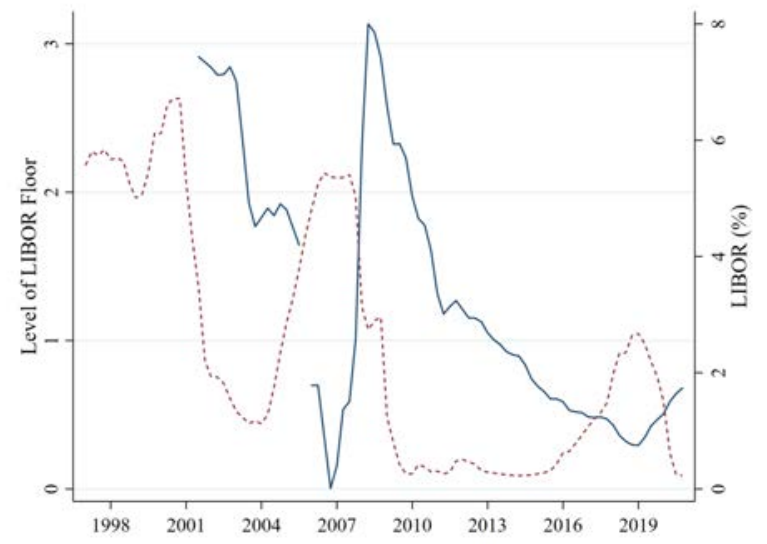

Panel E: Maturity

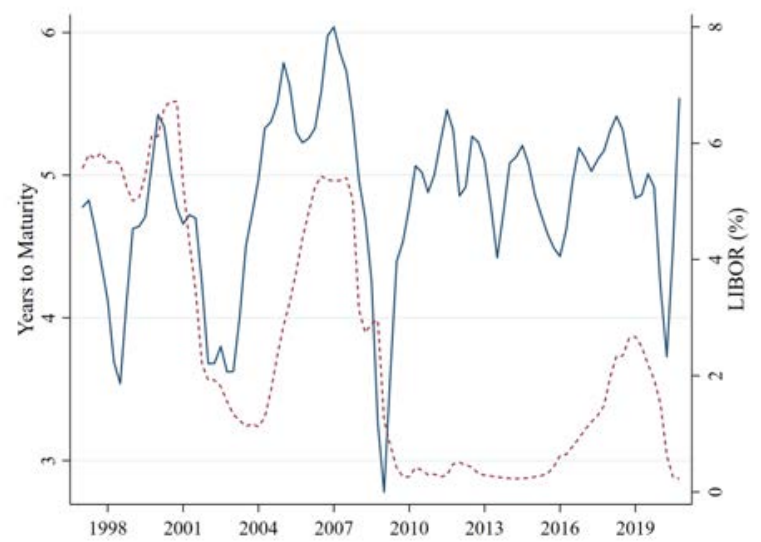

Panel B: Inclusion of LIBOR Floor

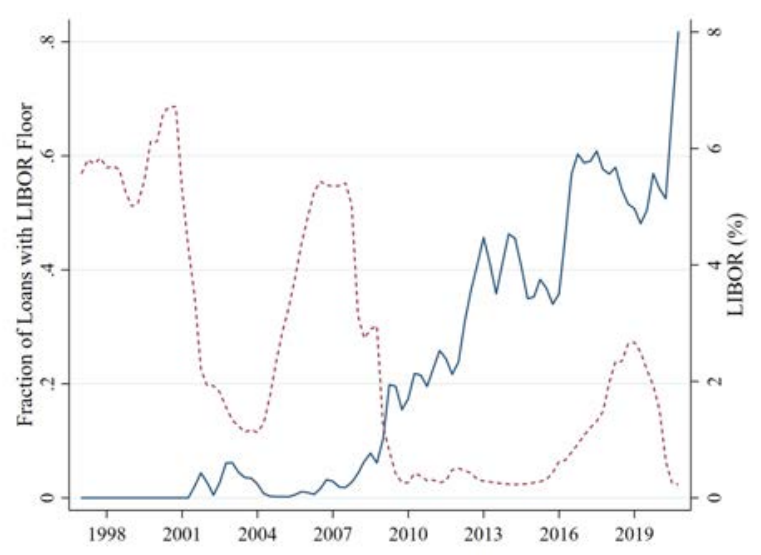

Panel D: Fraction of Binding Floors

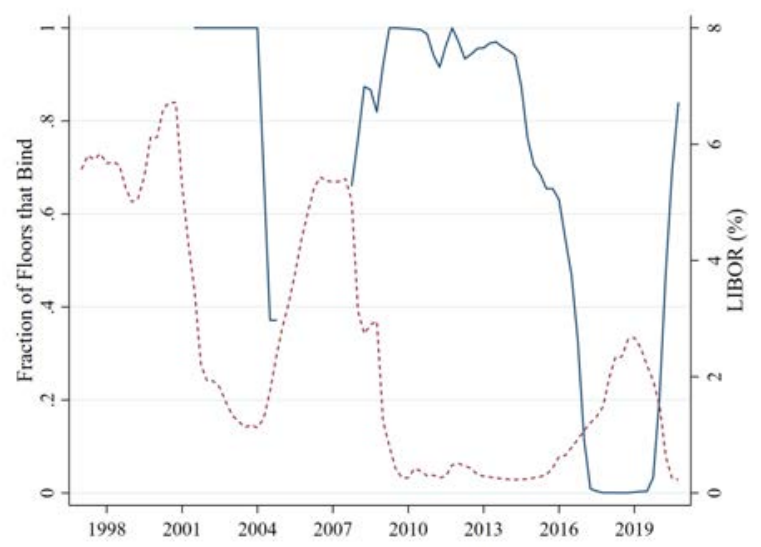

Panel F: Covenant-Lite Status

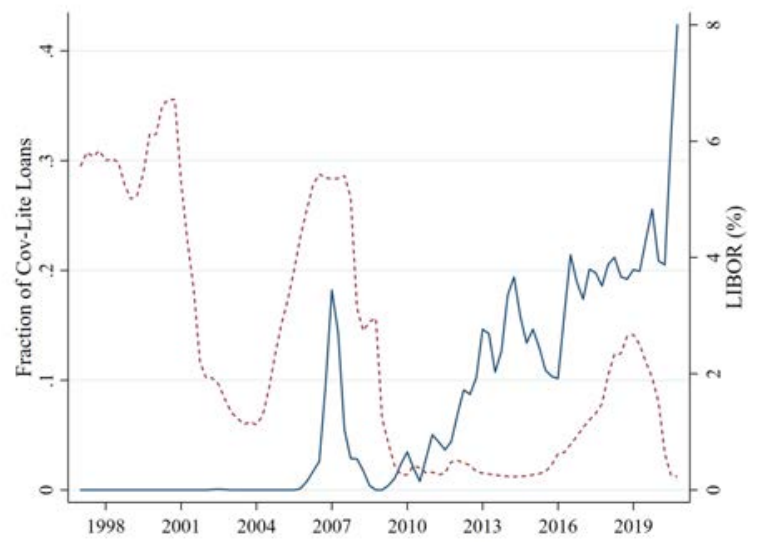




\section{Figure 3: Principal Components of the Treasury Yield Curve}

This figure presents the principal component (PC) loadings of the Treasury yield curve by time to maturity. Data on zero-coupon Treasury yields are from Gurkaynak, Sack, and Wright (2007). Following the literature, we refer to the PCs as Level, Slope, and Curvature.

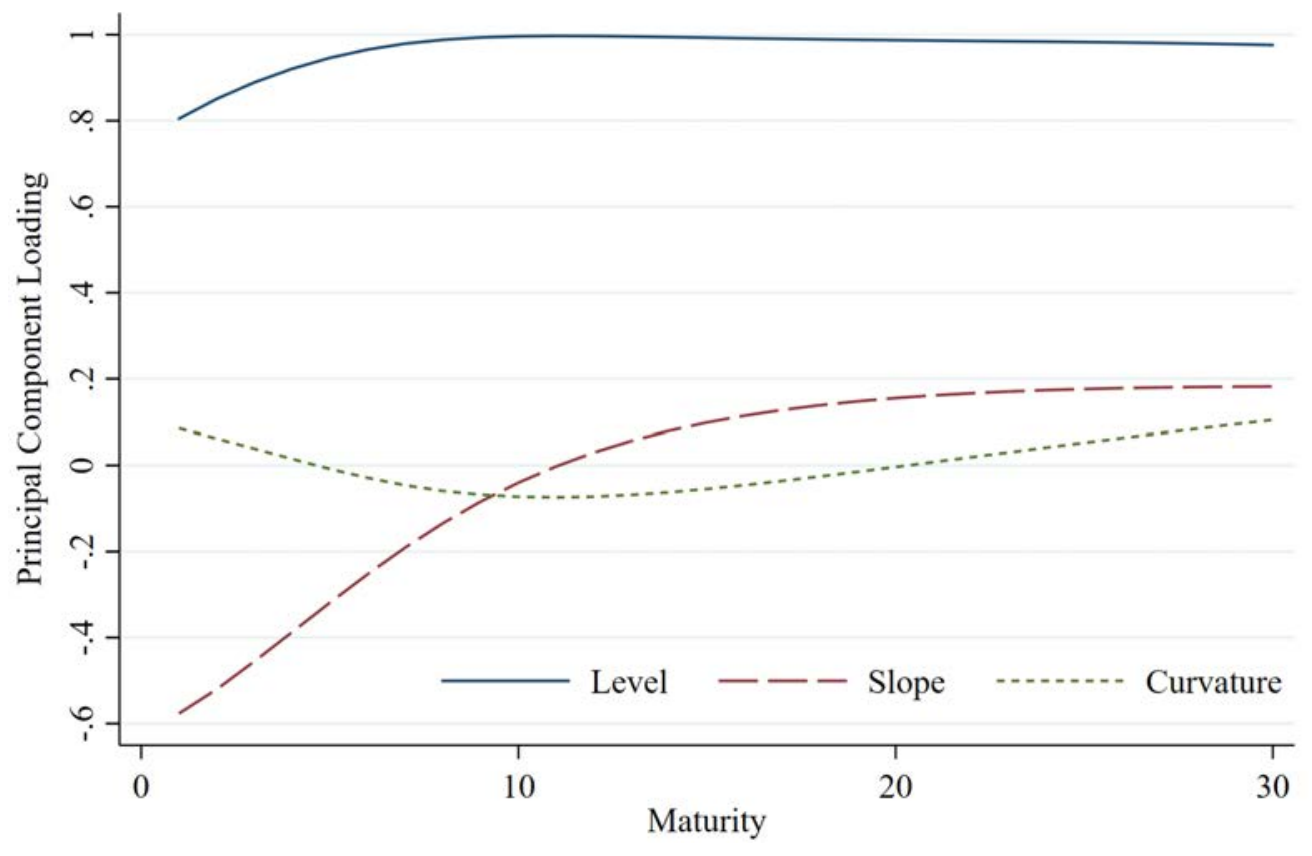


Figure 4: Merton (1974) Model Sensitivity of Credit Spreads to Risk-Free Rates

This figure presents simulated sensitivities of credit spreads to risk-free rates based on the Merton (1974) model. Both panels present the credit spread as a function of risk-free rates ranging from $0 \%$ to $10 \%$. The input parameters, when not specified otherwise, are $T=5$, $K / V=40 \%$, and $\sigma=50 \%$. Panel A considers alternative levels of leverage $(K / V): 80 \%$, $60 \%, 40 \%$, and $20 \%$. The slopes in this panel are $-0.37,-0.30,-0.20$, and -0.09 , respectively. Panel B varies the asset volatility $(\sigma): 70 \%, 60 \%, 50 \%$, and $40 \%$. The slopes in this panel are $-0.30,-0.26,-0.20$, and -0.14 , respectively.

Panel A: Leverage

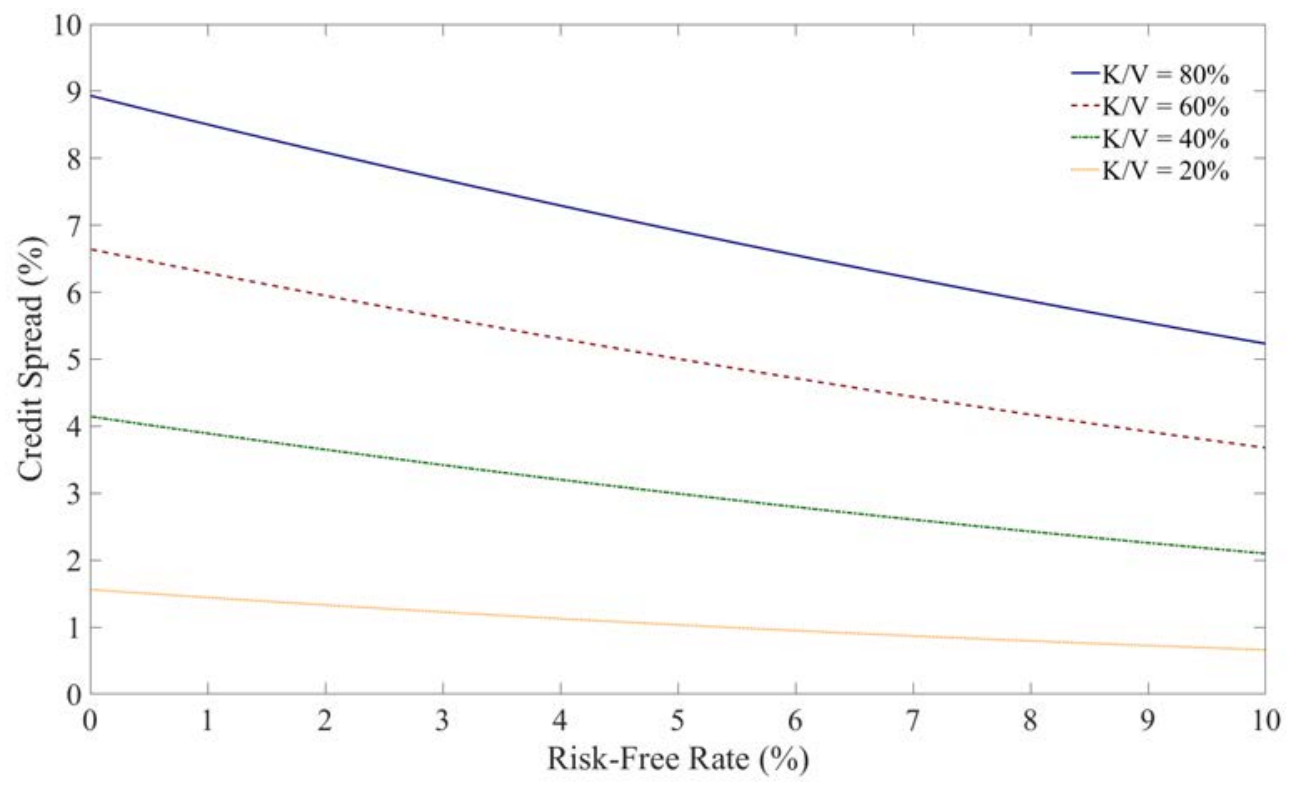

Panel B: Asset Volatility

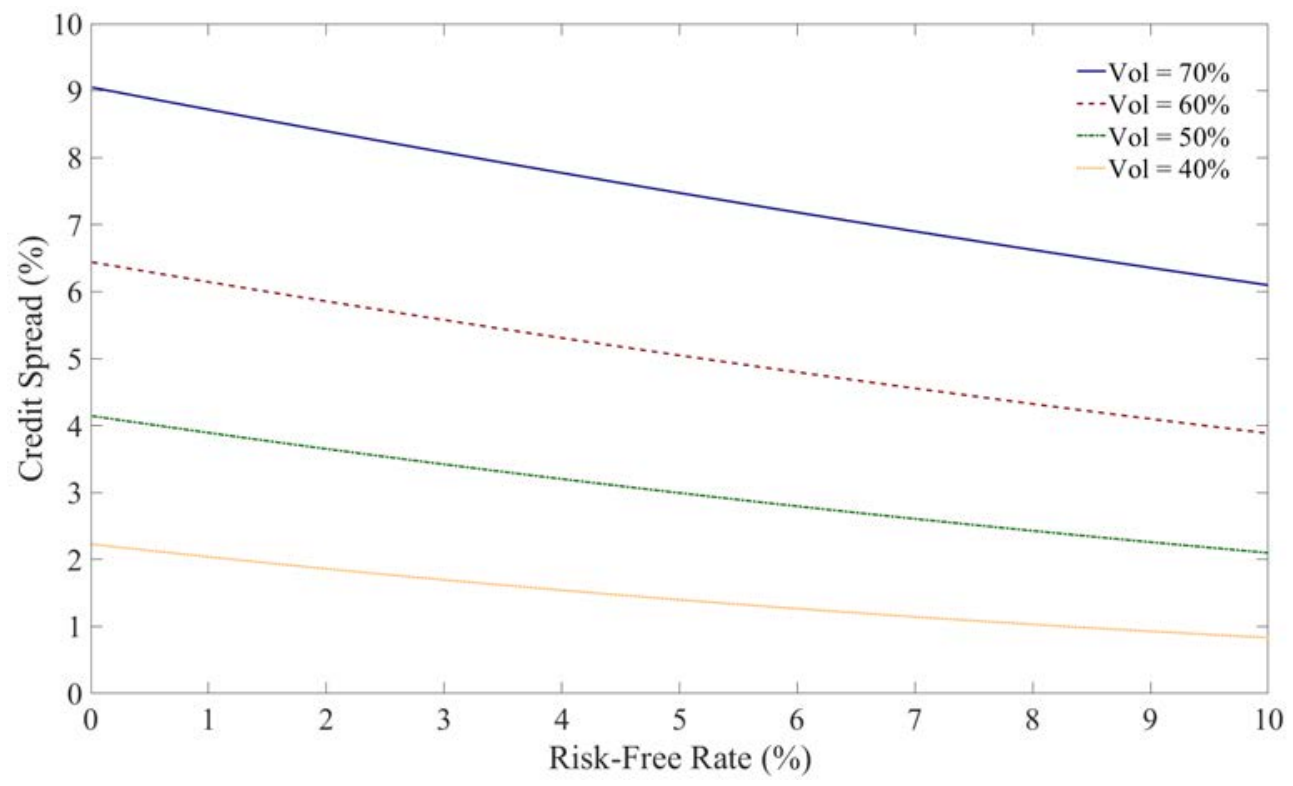


Figure 5: Empirical and Calibrated Model Sensitivities of Loan Spreads to Risk-Free Rates This figure presents the sensitivity of loan spreads to risk-free rates as a function of the loan's credit rating. The solid maroon line represents the Merton model-implied sensitivity, while the dashed navy line and shaded area represent the empirical sensitivity and $95 \%$ confidence band based on standard errors clustered by firm and year-quarter. Empirical sensitivities for the floor-adjusted spread are from the regression specification in Table 5, replacing LIBOR with the zero-coupon rate used in the Merton model analysis, which is bootstrapped from the LIBOR swap curve to match the loan's expected life. We obtain sensitivities for the Merton model predictions by estimating loan-level regressions of the model-implied sensitivity (from Panel B of Table 4) on indicators for loan credit rating.

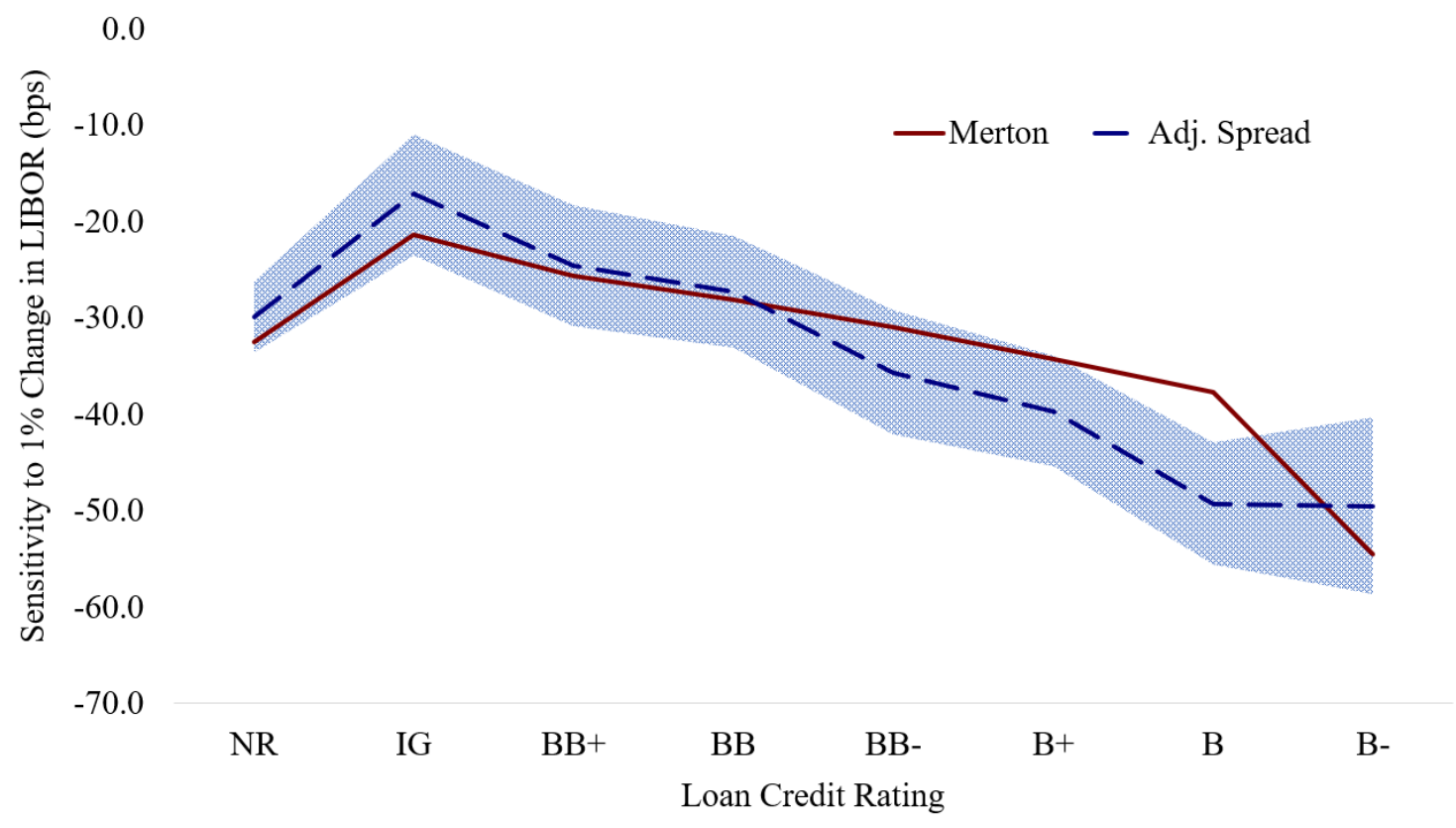


Figure 6: LIBOR Floors on CLO Tranches

This figure presents the fraction of newly issued CLOs with a LIBOR floor (blue line), along with the fraction of institutional term loans with a floor for comparison (red dashed line). For ease of presentation, each quarterly series is presented as a moving average with one-half weight on the current quarter and one-quarter weight on each of the neighboring quarters. Data are from Bloomberg.

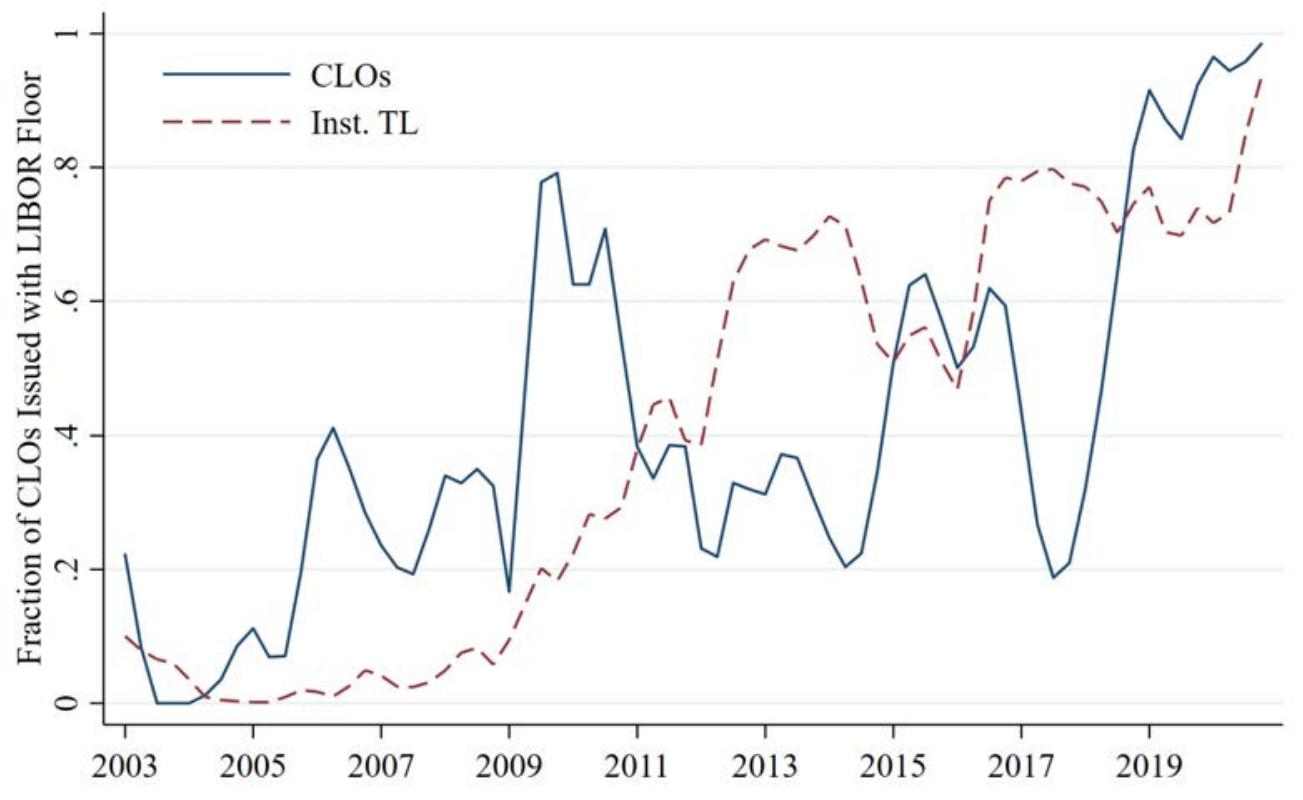




\section{Figure 7: Effect of LIBOR Floors on CLO Equity Distributions}

This figure illustrates the effect of LIBOR floors on the equity yields of collateralized loan obligations (CLOs). The calculation uses the principal value-weighted terms of loans and CLOs in each year from 2012 to 2018, including loan spreads, the inclusion of floors and their levels, the capital structure of CLOs, and the coupon rates paid on CLO tranche securities. The equity yield paid on the typical CLO in each year is calculated as the difference between coupons paid to the collateral pool and coupons paid on CLO tranche securities divided by the principal amount of the CLO equity tranche. The solid blue line reports the equity yield using the average loan spread, the fraction of loans with a LIBOR floor, and the average level of the LIBOR floor. The dashed red line is based on the alternative assumption that no loans have a floor. The dashed green line also assumes no loans have a floor but adjusts the loan spread upwards in an amount that offsets the theoretical value of the average LIBOR floor and fraction of loans with a floor each year.

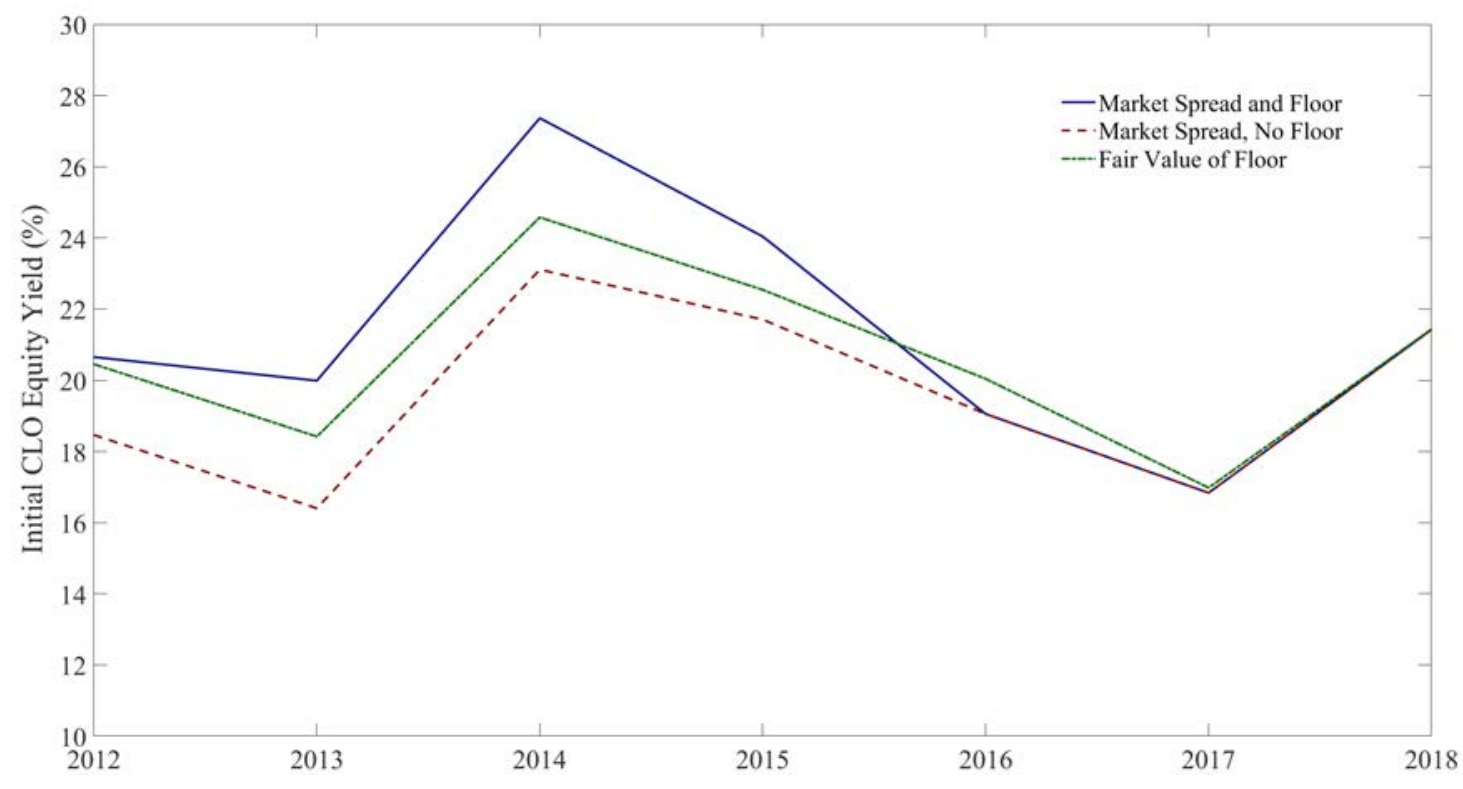


Table 1: Summary Statistics

This table presents summary statistics for the sample of loans (Panel A) and the macroeconomic variables used in our regression analysis (Panel B). The loan sample is restricted to U.S. dollar-denominated first-lien lines of credit and term loans with nonmissing information on spread, start date, and issue size. Variables denoted $1(\cdot)$ correspond to indicator variables. Floor Value is the spread adjustment implied by the Black (1976) value of the floor. Adjusted Spread is the spread of a floating-rate loan with the same value as the loan with a floor. Maturity is measured in years.

Panel A: Loan Characteristics

\begin{tabular}{lcccccccc}
\hline & Mean & Std.Dev. & Min. & p10 & p50 & p90 & Max. & Obs. \\
\hline Spread (\%) & 3.78 & 2.12 & 0.02 & 1.75 & 3.25 & 6.25 & 63.8 & 50,470 \\
1(Floor) & 0.37 & 0.48 & 0 & 0 & 0 & 1 & 1 & 50,470 \\
LIBOR Floor (\%) & 0.90 & 0.64 & 0 & 0 & 1.00 & 1.50 & 5.50 & 18,442 \\
Floor Value (\%) & 0.12 & 0.24 & 0 & 0 & 0 & 0.43 & 4.58 & 49,023 \\
$\quad$ (with Floor) & 0.36 & 0.29 & 0 & 0.11 & 0.28 & 0.76 & 4.58 & 16,995 \\
Adjusted Spread (\%) & 3.88 & 2.22 & 0.02 & 1.75 & 3.27 & 6.62 & 66.6 & 49,023 \\
Loan Amount (\$ MM) & 327.0 & 724.0 & 0.10 & 15.0 & 115.0 & 800.0 & 49,000 & 50,470 \\
Maturity & 5.29 & 1.72 & 0.03 & 3.00 & 5.00 & 7.00 & 39.8 & 48,067 \\
1(Cov-Lite) & 0.09 & 0.29 & 0 & 0 & 0 & 0 & 1 & 50,470 \\
1(Inst. TL) & 0.52 & 0.50 & 0 & 0 & 1 & 1 & 1 & 50,470 \\
1(IG-Rated) & 0.02 & 0.15 & 0 & 0 & 0 & 0 & 1 & 50,470 \\
1(BB-Rated) & 0.13 & 0.34 & 0 & 0 & 0 & 1 & 1 & 50,470 \\
1(B-Rated) & 0.17 & 0.38 & 0 & 0 & 0 & 1 & 1 & 50,470 \\
1(Non-Rated) & 0.67 & 0.47 & 0 & 0 & 1 & 1 & 1 & 50,470 \\
\hline
\end{tabular}

Panel B: Macroeconomic Variables

\begin{tabular}{lcccccccc}
\hline & Mean & Std.Dev. & Min. & p10 & p50 & p90 & Max. & Obs. \\
\hline LIBOR (\%) & 2.48 & 2.15 & 0.23 & 0.25 & 1.79 & 5.69 & 6.77 & 96 \\
Level PC & -0.01 & 1.03 & -2.06 & -1.24 & 0.09 & 1.38 & 2.02 & 96 \\
Slope PC & -0.03 & 1.00 & -1.46 & -1.26 & -0.26 & 1.52 & 1.85 & 96 \\
Curve PC & -0.05 & 1.01 & -5.16 & -0.93 & 0.18 & 1.02 & 1.33 & 96 \\
Yield Volatility (bp) & 86.40 & 27.70 & 38.65 & 54.98 & 83.17 & 118.62 & 194.90 & 96 \\
Equity CAPE & 27.42 & 6.17 & 13.32 & 20.91 & 26.67 & 36.96 & 42.76 & 96 \\
Real GDP Growth (\%) & 2.62 & 6.15 & -31.38 & -0.96 & 2.48 & 5.34 & 33.07 & 96 \\
1(Recession) & 0.13 & 0.33 & 0.00 & 0.00 & 0.00 & 1.00 & 1.00 & 96 \\
\hline
\end{tabular}


Table 2: Aggregate Determinants of Contract Terms - LIBOR

This table reports panel regressions of loan contract terms on macroeconomic variables. Each column has a different contract term as the dependent variable. Loan spreads and floors are in percentage terms and maturity is in years. Floor Val. is the spread adjustment implied by the Black (1976) value of the floor. Adj. Spread is the spread of a floating-rate loan with the same value as the loan with a floor. LIBOR is the three-month LIBOR rate on the loan's start date, in percentage terms. Equity CAPE is the cyclically adjusted price-earnings ratio from Robert Shiller's website. Real GDP Growth is lagged by one quarter. 1(Recession) is an indicator for NBER U.S. recession dates, lagged by one month. Panel A controls for loan credit rating and borrower industry indicators, log issue size, and indicators for revolving lines of credit and Term Loan A facilities. Panel B includes the same controls and adds borrower and lead arranger fixed effects. $t$-statistics based on standard errors clustered by firm and year-quarter are reported in parentheses. *, **, and *** denote $p$-values less than $0.10,0.05$, and 0.01 , respectively.

Panel A: No Fixed Effects

\begin{tabular}{lccccccc}
\hline Dependent Variable & Spread & 1(Floor) & Floor Level & Floor Val. & Adj. Spread & Maturity & 1(Cov-Lite) \\
\hline LIBOR (\%) & $-0.369^{* * *}$ & $-0.132^{* * *}$ & $0.144^{* * *}$ & $-0.043^{* * *}$ & $-0.412^{* * *}$ & $0.120^{* * *}$ & $-0.031^{* * *}$ \\
& $(-19.00)$ & $(-16.70)$ & $(3.14)$ & $(-12.48)$ & $(-19.00)$ & $(8.60)$ & $(-6.79)$ \\
Equity CAPE & $0.022^{* * *}$ & $0.025^{* * *}$ & $-0.116^{* * *}$ & 0.000 & $0.023^{* * *}$ & 0.003 & $0.012^{* * *}$ \\
& $(2.81)$ & $(5.96)$ & $(-10.27)$ & $(0.09)$ & $(2.69)$ & $(0.45)$ & $(5.19)$ \\
Real GDP Growth & -0.008 & $-0.004^{*}$ & 0.005 & 0.000 & -0.009 & $0.014^{* *}$ & -0.002 \\
& $(-0.80)$ & $(-1.67)$ & $(0.89)$ & $(0.08)$ & $(-0.60)$ & $(2.06)$ & $(-1.59)$ \\
1(Recession) & $0.563^{* * *}$ & -0.037 & $0.512^{* * *}$ & $0.124^{* *}$ & $0.663^{* * *}$ & $-0.646^{* * *}$ & -0.005 \\
& $(2.88)$ & $(-0.81)$ & $(3.10)$ & $(2.07)$ & $(2.68)$ & $(-5.05)$ & $(-0.28)$ \\
\hline Controls & $\mathrm{X}$ & $\mathrm{X}$ & $\mathrm{X}$ & $\mathrm{X}$ & $\mathrm{X}$ & $\mathrm{X}$ & $\mathrm{X}$ \\
Outcome Mean & 3.775 & 0.365 & 0.904 & 0.125 & 3.880 & 5.293 & 0.095 \\
Outcome SD & 2.116 & 0.482 & 0.638 & 0.242 & 2.220 & 1.718 & 0.293 \\
Adj. R & 0.358 & 0.313 & 0.427 & 0.213 & 0.371 & 0.140 & 0.167 \\
Observations & 50,448 & 50,448 & 18,431 & 49,001 & 49,001 & 48,046 & 50,448 \\
\hline
\end{tabular}


Panel B: Borrower and Lead Arranger Fixed Effects

\begin{tabular}{lccccccc}
\hline Dependent Variable & Spread & 1(Floor) & Floor Level & Floor Val. & Adj. Spread & Maturity & 1 (Cov-Lite) \\
\hline LIBOR (\%) & $-0.251^{* * *}$ & $-0.082^{* * *}$ & $0.096^{* * *}$ & $-0.035^{* * *}$ & $-0.286^{* * *}$ & $0.123^{* * *}$ & $-0.015^{* * *}$ \\
& $(-14.28)$ & $(-13.62)$ & $(2.79)$ & $(-10.35)$ & $(-14.31)$ & $(9.18)$ & $(-3.93)$ \\
Equity CAPE & 0.005 & $0.014^{* * *}$ & $-0.102^{* * *}$ & -0.002 & 0.004 & $0.010^{*}$ & $0.008^{* * *}$ \\
& $(0.58)$ & $(7.06)$ & $(-12.05)$ & $(-1.32)$ & $(0.41)$ & $(1.77)$ & $(4.67)$ \\
Real GDP Growth & $-0.006^{*}$ & $-0.004^{* * *}$ & 0.004 & -0.000 & -0.007 & $0.015^{* *}$ & $-0.002^{* * *}$ \\
& $(-1.75)$ & $(-3.76)$ & $(0.94)$ & $(-0.07)$ & $(-1.49)$ & $(2.18)$ & $(-3.02)$ \\
1(Recession) & $0.576^{* * *}$ & -0.018 & $0.495^{* * *}$ & $0.100^{* * *}$ & $0.662^{* * *}$ & $-0.731^{* * *}$ & -0.013 \\
& $(6.01)$ & $(-0.86)$ & $(3.82)$ & $(2.82)$ & $(6.14)$ & $(-6.46)$ & $(-1.49)$ \\
\hline Borrower FE & $\mathrm{X}$ & $\mathrm{X}$ & $\mathrm{X}$ & $\mathrm{X}$ & $\mathrm{X}$ & $\mathrm{X}$ & $\mathrm{X}$ \\
Lead Arranger FE & $\mathrm{X}$ & $\mathrm{X}$ & $\mathrm{X}$ & $\mathrm{X}$ & $\mathrm{X}$ & $\mathrm{X}$ & $\mathrm{X}$ \\
Controls & $\mathrm{X}$ & $\mathrm{X}$ & $\mathrm{X}$ & $\mathrm{X}$ & $\mathrm{X}$ & $\mathrm{X}$ & $\mathrm{X}$ \\
Outcome Mean & 3.514 & 0.360 & 0.885 & 0.122 & 3.618 & 5.367 & 0.103 \\
Outcome SD & 1.691 & 0.480 & 0.658 & 0.234 & 1.802 & 1.549 & 0.304 \\
Adj. R & 0.677 & 0.624 & 0.727 & 0.429 & 0.683 & 0.464 & 0.507 \\
Observations & 40,442 & 40,442 & 13,740 & 39,347 & 39,347 & 38,364 & 40,442 \\
\hline
\end{tabular}


Table 3: Aggregate Determinants of Contract Terms - Yield Curve Principal Components

This table reports panel regressions of loan contract terms on macroeconomic variables. Each column has a different contract term as the dependent variable. Loan spreads and floors are in percentage terms and maturity is in years. Floor Val. is the spread adjustment implied by the Black (1976) value of the floor. Adj. Spread is the spread of a floating-rate loan with the same value as the loan with a floor. Level and Slope PC are the first two principal components of the zero-coupon Treasury yield curve. Yield Volatility is the MOVE Index, a weighted average of implied volatilities from one-month options on the 2-year, 5-year, 10-year, and 30-year Treasury yields. Equity CAPE is the cyclically adjusted price-earnings ratio from Robert Shiller's website. Real GDP Growth is lagged by one quarter. 1(Recession) is an indicator for NBER U.S. recession dates, lagged by one month. Panel A controls for loan credit rating and borrower industry indicators, log issue size, and indicators for revolving lines of credit and Term Loan A facilities. Panel B includes the same controls and adds borrower and lead arranger fixed effects. $t$-statistics based on standard errors clustered by firm and year-quarter are reported in parentheses. ${ }^{*},{ }^{* *}$, and ${ }^{* * *}$ denote $p$-values less than $0.10,0.05$, and 0.01 , respectively.

Panel A: No Fixed Effects

\begin{tabular}{lccccccc}
\hline Dependent Variable & Spread & 1(Floor) & Floor Level & Floor Val. & Adj. Spread & Maturity & 1(Cov-Lite) \\
\hline Level PC & $-0.858^{* * *}$ & $-0.311^{* * *}$ & $0.390^{* * *}$ & $-0.103^{* * *}$ & $-0.967^{* * *}$ & $0.230^{* * *}$ & $-0.083^{* * *}$ \\
& $(-22.05)$ & $(-20.68)$ & $(6.20)$ & $(-14.59)$ & $(-23.91)$ & $(6.89)$ & $(-11.66)$ \\
Slope PC & $0.240^{* * *}$ & $0.046^{* * *}$ & -0.025 & $0.042^{* * *}$ & $0.280^{* * *}$ & $-0.131^{* * *}$ & $-0.011^{* *}$ \\
& $(5.79)$ & $(2.94)$ & $(-0.52)$ & $(5.62)$ & $(6.13)$ & $(-4.21)$ & $(-2.04)$ \\
Yield Volatility & 0.002 & $-0.001^{*}$ & $0.004^{* * *}$ & -0.000 & 0.002 & $-0.003^{*}$ & $-0.001^{* * *}$ \\
& $(1.20)$ & $(-1.82)$ & $(4.73)$ & $(-0.78)$ & $(0.91)$ & $(-1.96)$ & $(-2.71)$ \\
Equity CAPE & $0.021^{* *}$ & $0.020^{* * *}$ & $-0.073^{* * *}$ & 0.002 & $0.024^{* *}$ & -0.001 & $0.009^{* * *}$ \\
& $(2.28)$ & $(6.79)$ & $(-6.51)$ & $(1.13)$ & $(2.38)$ & $(-0.10)$ & $(6.05)$ \\
Real GDP Growth & 0.001 & -0.001 & 0.004 & 0.001 & 0.001 & 0.013 & -0.000 \\
& $(0.13)$ & $(-0.14)$ & $(1.58)$ & $(0.34)$ & $(0.13)$ & $(1.41)$ & $(-0.29)$ \\
1(Recession) & $0.339^{* *}$ & -0.068 & $0.649^{* * *}$ & $0.113^{* *}$ & $0.433^{* * *}$ & $-0.521^{* * *}$ & -0.007 \\
& $(2.61)$ & $(-1.10)$ & $(5.86)$ & $(2.29)$ & $(2.72)$ & $(-3.31)$ & $(-0.38)$ \\
\hline Controls & $\mathrm{X}$ & $\mathrm{X}$ & $\mathrm{X}$ & $\mathrm{X}$ & $\mathrm{X}$ & $\mathrm{X}$ & $\mathrm{X}$ \\
Outcome Mean & 3.775 & 0.365 & 0.904 & 0.125 & 3.880 & 5.293 & 0.095 \\
Outcome SD & 2.116 & 0.482 & 0.638 & 0.242 & 2.220 & 1.718 & 0.293 \\
Adj. R & 0.373 & 0.399 & 0.492 & 0.247 & 0.392 & 0.139 & 0.205 \\
Observations & 50,448 & 50,448 & 18,431 & 49,001 & 49,001 & 48,046 & 50,448 \\
\hline
\end{tabular}


Panel B: Borrower and Lead Arranger Fixed Effects

\begin{tabular}{lccccccc}
\hline Dependent Variable & Spread & 1 (Floor) & Floor Level & Floor Val. & Adj. Spread & Maturity & 1 (Cov-Lite) \\
\hline Level PC & $-0.522^{* * *}$ & $-0.234^{* * *}$ & $0.338^{* * *}$ & $-0.109^{* * *}$ & $-0.628^{* * *}$ & $0.342^{* * *}$ & $-0.079^{* * *}$ \\
& $(-12.75)$ & $(-17.85)$ & $(6.56)$ & $(-14.66)$ & $(-13.88)$ & $(8.43)$ & $(-9.87)$ \\
Slope PC & $0.284^{* * *}$ & $0.065^{* * *}$ & -0.038 & $0.038^{* * *}$ & $0.323^{* * *}$ & $-0.057^{* *}$ & $-0.012^{* *}$ \\
& $(7.98)$ & $(6.29)$ & $(-0.90)$ & $(6.63)$ & $(8.21)$ & $(-2.23)$ & $(-2.33)$ \\
Yield Volatility & $0.007^{* * *}$ & -0.000 & $0.004^{* * *}$ & -0.000 & $0.007^{* * *}$ & $-0.003^{* *}$ & $-0.000^{* *}$ \\
& $(4.78)$ & $(-1.21)$ & $(5.80)$ & $(-0.10)$ & $(4.30)$ & $(-2.06)$ & $(-2.19)$ \\
Equity CAPE & $0.015^{*}$ & $0.016^{* * *}$ & $-0.082^{* * *}$ & 0.001 & $0.017^{*}$ & $0.011^{*}$ & $0.008^{* * *}$ \\
& $(1.80)$ & $(8.29)$ & $(-8.01)$ & $(0.65)$ & $(1.74)$ & $(1.88)$ & $(5.40)$ \\
Real GDP Growth & -0.002 & -0.002 & $0.004^{*}$ & 0.000 & -0.002 & $0.011^{*}$ & -0.001 \\
& $(-0.39)$ & $(-0.98)$ & $(1.93)$ & $(0.20)$ & $(-0.31)$ & $(1.91)$ & $(-1.04)$ \\
1(Recession) & $0.267^{* *}$ & -0.047 & $0.620^{* * *}$ & $0.082^{* * *}$ & $0.340^{* * *}$ & $-0.589^{* * *}$ & -0.015 \\
& $(2.48)$ & $(-1.33)$ & $(6.93)$ & $(2.72)$ & $(2.74)$ & $(-5.68)$ & $(-1.21)$ \\
\hline Borrower FE & $\mathrm{X}$ & $\mathrm{X}$ & $\mathrm{X}$ & $\mathrm{X}$ & $\mathrm{X}$ & $\mathrm{X}$ & $\mathrm{X}$ \\
Lead Arranger FE & $\mathrm{X}$ & $\mathrm{X}$ & $\mathrm{X}$ & $\mathrm{X}$ & $\mathrm{X}$ & $\mathrm{X}$ & $\mathrm{X}$ \\
Controls & $\mathrm{X}$ & $\mathrm{X}$ & $\mathrm{X}$ & $\mathrm{X}$ & $\mathrm{X}$ & $\mathrm{X}$ & $\mathrm{X}$ \\
Outcome Mean & 3.514 & 0.360 & 0.885 & 0.122 & 3.618 & 5.367 & 0.103 \\
Outcome SD & 1.691 & 0.480 & 0.658 & 0.234 & 1.802 & 1.549 & 0.304 \\
Adj. R ${ }^{2}$ & 0.682 & 0.635 & 0.759 & 0.448 & 0.689 & 0.465 & 0.520 \\
Observations & 40,442 & 40,442 & 13,740 & 39,347 & 39,347 & 38,364 & 40,442 \\
\hline
\end{tabular}


Table 4: Merton (1974) Model Sensitivity of Loan Spreads to Risk-Free Rates

This table reports the sensitivity of loan spreads to risk-free rates in the Merton (1974) model calibrated to the borrowers and loan terms in our sample. For each loan, we compute the modelimplied change in the credit spread over the risk-free rate with respect to a one percentage point change in the risk-free rate. We summarize the distribution of these sensitivities for the full sample and by loan credit rating, grouping the investment-grade (IG) loans together. We calibrate asset volatility in the model to match the observed loan spread, setting the risk-free rate to maturitymatched zero-coupon LIBOR rate interpolated from the swap curve, the expected life of the debt to the loan's contractual maturity times the average ratio of realized life to contractual maturity by credit rating (to account for prepayment), and the face value of debt equal to the borrower's loan debt outstanding at the prior quarter-end plus the face value of the present loan. Panel A is based on observable capital structure information from the intersection of the IHS Markit sample, Dealscan, and Capital IQ. Panel B is based on the full sample, interpolating the capital structure data for loans that could not be matched to Capital IQ by using the average loan-to-assets ratio by credit rating.

Panel A: Intersection of IHS Markit, Dealscan, and Capital IQ

\begin{tabular}{lccccccccc}
\hline Loan Rating & Any & IG & BB + & BB & BB- & B + & B & B- & NR \\
\hline Mean & -0.294 & -0.224 & -0.270 & -0.297 & -0.331 & -0.347 & -0.385 & -0.481 & -0.277 \\
St. Dev. & 0.172 & 0.119 & 0.153 & 0.170 & 0.169 & 0.178 & 0.180 & 0.158 & 0.170 \\
p25 & -0.384 & -0.270 & -0.333 & -0.367 & -0.427 & -0.465 & -0.538 & -0.675 & -0.359 \\
p50 & -0.247 & -0.196 & -0.235 & -0.247 & -0.288 & -0.297 & -0.350 & -0.452 & -0.230 \\
p75 & -0.165 & -0.145 & -0.152 & -0.170 & -0.194 & -0.199 & -0.230 & -0.358 & -0.147 \\
Expected Life & 0.630 & 0.597 & 0.470 & 0.485 & 0.486 & 0.505 & 0.451 & 0.477 & 0.751 \\
Observations & 4,036 & 217 & 240 & 415 & 502 & 358 & 151 & 33 & 2,120 \\
\hline
\end{tabular}

Panel B: Full Sample, with Leverage Imputed by Credit Rating

\begin{tabular}{lccccccccc}
\hline Loan Rating & Any & IG & BB + & BB & BB- & B + & B & B- & NR \\
\hline Mean & -0.330 & -0.214 & -0.257 & -0.281 & -0.310 & -0.343 & -0.377 & -0.545 & -0.325 \\
St. Dev. & 0.109 & 0.083 & 0.092 & 0.102 & 0.095 & 0.090 & 0.085 & 0.111 & 0.104 \\
p25 & -0.408 & -0.257 & -0.301 & -0.335 & -0.363 & -0.402 & -0.435 & -0.652 & -0.403 \\
p50 & -0.328 & -0.214 & -0.250 & -0.269 & -0.300 & -0.331 & -0.380 & -0.560 & -0.325 \\
p75 & -0.258 & -0.164 & -0.205 & -0.213 & -0.249 & -0.284 & -0.314 & -0.457 & -0.258 \\
Expected Life & 0.655 & 0.597 & 0.470 & 0.485 & 0.486 & 0.505 & 0.451 & 0.477 & 0.751 \\
Observations & 47,080 & 983 & 1,154 & 1,932 & 3,249 & 4,144 & 3,085 & 728 & 26,140 \\
\hline
\end{tabular}


Table 5: Cross-Sectional Determinants of Contract Terms

This table reports panel regressions of loan contract terms on LIBOR interacted with cross-sectional proxies for lender hedging demand and borrower moral hazard. Panel A uses indicators for the loan credit rating, with investment-grade loans as the baseline group. Each column has a different contract term as the dependent variable. Panel B uses indicators for terciles of the lead arranger's income gap, with the bottom tercile (lowest income gap) as the baseline group for both. Panel $\mathrm{C}$ uses an indicator for institutional term loans, with pro rata loans as the baseline group. Loan spreads and floors are in percentage terms and maturity is in years. Floor Val. is the spread adjustment implied by the Black (1976) value of the floor. Adj. Spread is the spread of a floatingrate loan with the same value as the loan with a floor. Panel A includes lead arranger fixed effects but not borrower fixed effects, due to insufficient within-borrower variation in credit rating. Panel $B$ includes borrower fixed effects but no lead arranger fixed effects, due to insufficient within-bank variation in income gap. Panel $\mathrm{C}$ includes borrower and lead arranger fixed effects. All of the specifications control for loan type, credit rating, and borrower industry indicators, log issue size, and the macroeconomic variables from Tables 2 and 3 : GDP Growth, Unemployment, and a U.S. recession indicator. $t$-statistics based on standard errors clustered by firm and year-quarter are reported in parentheses. ${ }^{*}, * *$, and $* * *$ denote $p$-values less than $0.10,0.05$, and 0.01 , respectively.

Panel A: Loan Credit Ratings

\begin{tabular}{lccccc}
\hline Dependent Variable & Spread & 1 (Floor) & Floor Level & Floor Val. & Adj. Spread \\
\hline LIBOR $(\%)$ & $-0.135^{* * *}$ & $-0.102^{* * *}$ & $0.211^{* *}$ & $-0.020^{* * *}$ & $-0.153^{* * *}$ \\
& $(-4.99)$ & $(-9.67)$ & $(2.51)$ & $(-4.32)$ & $(-5.25)$ \\
LIBOR $\times 1$ (BB+ Rated) & $-0.044^{*}$ & -0.017 & -0.096 & $-0.009^{*}$ & $-0.056^{*}$ \\
& $(-1.66)$ & $(-1.65)$ & $(-1.26)$ & $(-1.88)$ & $(-1.89)$ \\
LIBOR $\times 1$ (BB Rated) & $-0.048^{* *}$ & $-0.030^{* * *}$ & -0.119 & $-0.015^{* *}$ & $-0.062^{* *}$ \\
& $(-2.05)$ & $(-2.68)$ & $(-1.63)$ & $(-2.59)$ & $(-2.30)$ \\
LIBOR $\times 1$ (BB- Rated) & $-0.106^{* * *}$ & $-0.044^{* * *}$ & $-0.181^{* *}$ & $-0.030^{* * *}$ & $-0.137^{* * *}$ \\
& $(-3.91)$ & $(-4.05)$ & $(-2.62)$ & $(-4.91)$ & $(-4.44)$ \\
LIBOR $\times 1$ (B+ Rated) & $-0.148^{* * *}$ & $-0.041^{* * *}$ & $-0.211^{* * *}$ & $-0.032^{* * *}$ & $-0.177^{* * *}$ \\
& $(-5.67)$ & $(-3.72)$ & $(-2.86)$ & $(-4.77)$ & $(-5.88)$ \\
LIBOR $\times 1$ (B Rated) & $-0.226^{* * *}$ & $-0.046^{* * *}$ & $-0.217^{* * *}$ & $-0.049^{* * *}$ & $-0.278^{* * *}$ \\
& $(-6.98)$ & $(-4.33)$ & $(-2.92)$ & $(-6.07)$ & $(-7.62)$ \\
LIBOR $\times 1$ (B- Rated) & $-0.237^{* * *}$ & $-0.043^{* * *}$ & $-0.204^{* *}$ & $-0.046^{* * *}$ & $-0.282^{* * *}$ \\
& $(-5.32)$ & $(-3.55)$ & $(-2.61)$ & $(-6.01)$ & $(-5.83)$ \\
LIBOR $\times 1$ (Non-Rated) & $-0.106^{* * *}$ & 0.003 & -0.044 & $-0.009^{* *}$ & $-0.116^{* * *}$ \\
& $(-4.33)$ & $(0.40)$ & $(-0.68)$ & $(-2.25)$ & $(-4.33)$ \\
\hline Lead Arranger FE & $\mathrm{X}$ & $\mathrm{X}$ & $\mathrm{X}$ & $\mathrm{X}$ & $\mathrm{X}$ \\
Controls & $\mathrm{X}$ & $\mathrm{X}$ & $\mathrm{X}$ & $\mathrm{X}$ & $\mathrm{X}$ \\
Outcome Mean & 3.513 & 0.358 & 0.885 & 0.120 & 3.614 \\
Outcome SD & 1.737 & 0.479 & 0.656 & 0.233 & 1.847 \\
Adj. R ${ }^{2}$ & 0.446 & 0.431 & 0.517 & 0.279 & 0.462 \\
Observations & 43,091 & 43,091 & 15,426 & 41,902 & 41,902 \\
\hline
\end{tabular}


Panel B: Lead Arranger Income Gap

\begin{tabular}{lccccc}
\hline Dependent Variable & Spread & 1(Floor) & Floor Level & Floor Val. & Adj. Spread \\
\hline LIBOR (\%) & $-0.233^{* * *}$ & $-0.075^{* * *}$ & -0.001 & $-0.026^{* * *}$ & $-0.257^{* * *}$ \\
& $(-12.13)$ & $(-10.62)$ & $(-0.03)$ & $(-7.85)$ & $(-12.25)$ \\
LIBOR $\times$ 1(Inc. Gap. Q2) & -0.018 & 0.002 & 0.050 & $0.005^{*}$ & -0.015 \\
& $(-0.95)$ & $(0.40)$ & $(0.66)$ & $(1.70)$ & $(-0.71)$ \\
LIBOR $\times$ 1(Inc. Gap. Q3) & $-0.055^{* *}$ & 0.009 & 0.005 & -0.003 & $-0.059^{* *}$ \\
& $(-2.28)$ & $(1.49)$ & $(0.08)$ & $(-0.77)$ & $(-2.23)$ \\
1(Inc. Gap. Q2) & 0.074 & 0.015 & -0.049 & -0.002 & 0.080 \\
& $(1.03)$ & $(0.64)$ & $(-0.68)$ & $(-0.19)$ & $(1.01)$ \\
1(Inc. Gap. Q3) & $0.231^{* * *}$ & -0.015 & -0.015 & 0.017 & $0.252^{* * *}$ \\
& $(2.89)$ & $(-0.64)$ & $(-0.28)$ & $(1.12)$ & $(2.87)$ \\
\hline Borrower FE & $\mathrm{X}$ & $\mathrm{X}$ & $\mathrm{X}$ & $\mathrm{X}$ & $\mathrm{X}$ \\
Controls & $\mathrm{X}$ & $\mathrm{X}$ & $\mathrm{X}$ & $\mathrm{X}$ & $\mathrm{X}$ \\
Outcome Mean & 3.018 & 0.258 & 0.955 & 0.093 & 3.094 \\
Outcome SD & 1.505 & 0.438 & 0.720 & 0.213 & 1.603 \\
Adj. R & 0.611 & 0.570 & 0.763 & 0.409 & 0.616 \\
Observations & 15,969 & 15,969 & 3,726 & 15,641 & 15,641 \\
\hline
\end{tabular}

Panel C: Institutional vs. Pro Rata Loans

\begin{tabular}{lccccc}
\hline Dependent Variable & Spread & 1(Floor) & Floor Level & Floor Val. & Adj. Spread \\
\hline LIBOR (\%) & $-0.230^{* * *}$ & $-0.055^{* * *}$ & $0.124^{* * *}$ & $-0.018^{* * *}$ & $-0.247^{* * *}$ \\
& $(-13.82)$ & $(-9.74)$ & $(3.55)$ & $(-6.28)$ & $(-13.19)$ \\
LIBOR $\times$ 1(Inst. TL) & $-0.040^{* * *}$ & $-0.050^{* * *}$ & $-0.034^{*}$ & $-0.032^{* * *}$ & $-0.072^{* * *}$ \\
& $(-5.93)$ & $(-9.27)$ & $(-1.86)$ & $(-8.65)$ & $(-8.46)$ \\
1(Inst. TL) & $0.609^{* * *}$ & $0.224^{* * *}$ & $0.217^{* * *}$ & $0.135^{* * *}$ & $0.748^{* * *}$ \\
& $(20.00)$ & $(9.75)$ & $(6.46)$ & $(9.09)$ & $(19.73)$ \\
\hline Borrower FE & $\mathrm{X}$ & $\mathrm{X}$ & $\mathrm{X}$ & $\mathrm{X}$ & $\mathrm{X}$ \\
Lead Arranger FE & $\mathrm{X}$ & $\mathrm{X}$ & $\mathrm{X}$ & $\mathrm{X}$ & $\mathrm{X}$ \\
Controls & $\mathrm{X}$ & $\mathrm{X}$ & $\mathrm{X}$ & $\mathrm{X}$ & $\mathrm{X}$ \\
Outcome Mean & 3.514 & 0.360 & 0.885 & 0.122 & 3.618 \\
Outcome SD & 1.691 & 0.480 & 0.658 & 0.234 & 1.802 \\
Adj. R & 0.677 & 0.636 & 0.728 & 0.450 & 0.685 \\
Observations & 40,442 & 40,442 & 13,740 & 39,347 & 39,347 \\
\hline
\end{tabular}


Table 6: Borrower Credit Risk and LIBOR Floors

This table reports panel regressions of the LIBOR floor indicator on loan credit rating indicators. Investment-grade loans are the omitted baseline category. Controls include loan type and borrower industry indicators, log issue size, and the macroeconomic variables from Tables 2 and 3 ; GDP Growth, Unemployment, and a U.S. recession indicator. $t$-statistics based on standard errors clustered by firm and year-quarter are reported in parentheses. ${ }^{*},{ }^{* *}$, and ${ }^{* * *}$ denote $p$-values less than $0.10,0.05$, and 0.01 , respectively.

\begin{tabular}{lcccc}
\hline 1(Floor) & $(1)$ & $(2)$ & $(3)$ & $(4)$ \\
\hline 1 (BB+ Rated) & 0.048 & $0.095^{* * *}$ & $0.065^{* * *}$ & $0.058^{* * *}$ \\
& $(1.48)$ & $(4.27)$ & $(2.98)$ & $(2.79)$ \\
1 (BB Rated) & -0.007 & $0.104^{* * *}$ & $0.080^{* * *}$ & $0.067^{* * *}$ \\
& $(-0.21)$ & $(4.73)$ & $(3.77)$ & $(3.36)$ \\
1 (BB- Rated) & 0.012 & $0.136^{* * *}$ & $0.090^{* * *}$ & $0.072^{* * *}$ \\
& $(0.31)$ & $(5.00)$ & $(3.71)$ & $(3.16)$ \\
1 (B+ Rated) & -0.003 & $0.128^{* * *}$ & $0.079^{* * *}$ & $0.056^{* *}$ \\
& $(-0.08)$ & $(4.69)$ & $(3.26)$ & $(2.49)$ \\
1(B Rated) & $0.268^{* * *}$ & $0.199^{* * *}$ & $0.137^{* * *}$ & $0.110^{* * *}$ \\
& $(5.49)$ & $(7.14)$ & $(5.53)$ & $(4.81)$ \\
1 (B- Rated) & $0.244^{* * *}$ & $0.172^{* * *}$ & $0.113^{* * *}$ & $0.088^{* * *}$ \\
& $(4.30)$ & $(6.09)$ & $(4.60)$ & $(3.89)$ \\
1(Non-Rated) & 0.016 & $-0.039^{* *}$ & $-0.085^{* * *}$ & $-0.073^{* * *}$ \\
& $(0.56)$ & $(-2.22)$ & $(-4.30)$ & $(-3.75)$ \\
\hline Year-Quarter FE & & $\mathrm{X}$ & $\mathrm{X}$ & $\mathrm{X}$ \\
Lead Arranger FE & & & $\mathrm{X}$ & $\mathrm{X}$ \\
Controls & & & & $\mathrm{X}$ \\
Adj. R & & 0.434 & 0.511 & 0.538 \\
Observations & 50,470 & 50,470 & 43,104 & 43,103 \\
\hline
\end{tabular}




\section{Table 7: Borrower Risk, Future Rate Expectations, and Contract Design}

This table reports panel regressions of loan contract terms on the level, slope, and volatility of the yield curve interacted loan credit rating indicators. We report only the interaction coefficients on the Slope PC for brevity, but each specification includes interactions with the Level PC and Yield Volatility. Level and Slope PC are the first two principal components of the zero-coupon Treasury yield curve. Yield Volatility is the MOVE Index, a weighted average of implied volatilities from one-month options on the 2-year, 5-year, 10-year, and 30-year Treasury yields. The regression includes lead arranger fixed effects but not borrower fixed effects, due to insufficient within-borrower variation in credit rating. Investment-grade loans are the omitted rating category. All of the specifications control for loan type, credit rating, and borrower industry indicators, log issue size, and the macroeconomic variables from Tables 2 and 3 . GDP Growth, Unemployment, and a U.S. recession indicator. $t$-statistics based on standard errors clustered by firm and year-quarter are reported in parentheses. ${ }^{*}, * *$, and $* * *$ denote $p$-values less than $0.10,0.05$, and 0.01 , respectively.

\begin{tabular}{lccc}
\hline Dependent Variable & 1 (Floor) & Floor Level & 1 (Cov-Lite) \\
\hline Slope PC & 0.017 & -0.049 & $-0.030^{*}$ \\
& $(0.63)$ & $(-0.68)$ & $(-1.91)$ \\
Slope PC $\times 1$ (BB+ Rated) & -0.006 & 0.072 & -0.026 \\
& $(-0.22)$ & $(1.32)$ & $(-1.32)$ \\
Slope PC $\times 1$ (BB Rated) & 0.024 & 0.085 & 0.001 \\
& $(0.92)$ & $(1.20)$ & $(0.05)$ \\
Slope PC $\times 1$ (BB- Rated) & $0.072^{* * *}$ & $0.106^{*}$ & -0.006 \\
& $(3.19)$ & $(1.74)$ & $(-0.40)$ \\
Slope PC $\times 1$ (B+ Rated) & $0.074^{* * *}$ & $0.139^{* *}$ & -0.008 \\
& $(2.96)$ & $(2.16)$ & $(-0.51)$ \\
Slope PC $\times 1$ (B Rated) & $0.075^{* * *}$ & $0.165^{* *}$ & $-0.062^{* * *}$ \\
& $(3.44)$ & $(2.54)$ & $(-3.73)$ \\
Slope PC $\times 1$ (B- Rated) & $0.067^{* *}$ & $0.146^{* *}$ & -0.033 \\
& $(2.31)$ & $(2.10)$ & $(-1.59)$ \\
Slope PC $\times 1$ (Non-Rated) & 0.025 & 0.046 & $0.039^{* *}$ \\
& $(1.05)$ & $(0.84)$ & $(2.42)$ \\
\hline Level PC $\times$ Rating & $\mathrm{X}$ & $\mathrm{X}$ & $\mathrm{X}$ \\
Yield Vol. $\times$ Rating & $\mathrm{X}$ & $\mathrm{X}$ & $\mathrm{X}$ \\
Lead Arranger FE & $\mathrm{X}$ & $\mathrm{X}$ & $\mathrm{X}$ \\
Controls & $\mathrm{X}$ & $\mathrm{X}$ & $\mathrm{X}$ \\
Adj. R & 0.495 & 0.596 & 0.301 \\
Observations & 43,091 & 15,426 & 43,091 \\
\hline
\end{tabular}

